Cochrane Database of Systematic Reviews

\title{
Corticosteroids as standalone or add-on treatment for sore throat
} (Review)

de Cassan S, Thompson MJ, Perera R, Glasziou PP, Del Mar CB, Heneghan CJ, Hayward G

de Cassan S, Thompson MJ, Perera R, Glasziou PP, Del Mar CB, Heneghan CJ, Hayward G.

Corticosteroids as standalone or add-on treatment for sore throat.

Cochrane Database of Systematic Reviews 2020, Issue 5. Art. No.: CD008268.

DOI: 10.1002/14651858.CD008268.pub3.

www.cochranelibrary.com 
TABLE OF CONTENTS

HEADER 1

ABSTRACT

PLAIN LANGUAGE SUMMARY

SUMMARY OF FINDINGS

BACKGROUND

OBJECTIVES

METHODS

Figure 1.

RESULTS

Figure 2.

Figure 3.

Figure 4.

Figure 5.

Figure 6.

DISCUSSION

AUTHORS' CONCLUSIONS

ACKNOWLEDGEMENTS

REFERENCES

CHARACTERISTICS OF STUDIES

DATA AND ANALYSES

Analysis 1.1. Comparison 1: Corticosteroids versus placebo, Outcome 1: Complete resolution of pain at 24 hours ..................

Analysis 1.2. Comparison 1: Corticosteroids versus placebo, Outcome 2: Complete resolution of pain at 24 hours: route of corticosteroid administration

Analysis 1.3. Comparison 1: Corticosteroids versus placebo, Outcome 3: Complete resolution of pain at 48 hours ...................

Analysis 1.4. Comparison 1: Corticosteroids versus placebo, Outcome 4: Mean time to onset of pain relief

Analysis 1.5. Comparison 1: Corticosteroids versus placebo, Outcome 5: Mean time to onset of pain relief by bacterial pathogen positive/negative

Analysis 1.6. Comparison 1: Corticosteroids versus placebo, Outcome 6: Mean time to onset of pain relief in exudative/not exudative sore throat

Analysis 1.7. Comparison 1: Corticosteroids versus placebo, Outcome 7: Mean time to onset of pain relief in severe/not severe sore throat

Analysis 1.8. Comparison 1: Corticosteroids versus placebo, Outcome 8: Mean time to onset of pain relief by route of corticosteroid administration

Analysis 1.9. Comparison 1: Corticosteroids versus placebo, Outcome 9: Mean time to complete resolution of pain

Analysis 1.10. Comparison 1: Corticosteroids versus placebo, Outcome 10: Mean absolute reduction in pain VAS/McGrath scale at 24 hours

Analysis 1.11. Comparison 1: Corticosteroids versus placebo, Outcome 11: Adverse events

Analysis 1.12. Comparison 1: Corticosteroids versus placebo, Outcome 12: Relapse rates of symptoms

Analysis 1.13. Comparison 1: Corticosteroids versus placebo, Outcome 13: Days missed from work or school APPENDICES

FEEDBACK

WHAT'S NEW

HISTORY

CONTRIBUTIONS OF AUTHORS

DECLARATIONS OF INTEREST

SOURCES OF SUPPORT

DIFFERENCES BETWEEN PROTOCOL AND REVIEW

INDEX TERMS 
[Intervention Review]

\section{Corticosteroids as standalone or add-on treatment for sore throat}

Simone de Cassan ${ }^{1}$, Matthew J Thompson², Rafael Perera 3 , Paul P Glasziou 4 , Chris B Del Mar 4 , Carl J Heneghan³, Gail Hayward 3

1Department of Psychiatry, University of Oxford, Oxford, UK. 2Department of Family Medicine, University of Washington, Seattle, WA, USA. ${ }^{3}$ Nuffield Department of Primary Care Health Sciences, University of Oxford, Oxford, UK. ${ }^{4}$ Centre for Research in Evidence-Based Practice (CREBP), Bond University, Gold Coast, Australia

Contact address: Matthew J Thompson, mjt@uw.edu, matthew.thompson61@gmail.com.

Editorial group: Cochrane Acute Respiratory Infections Group.

Publication status and date: New search for studies and content updated (conclusions changed), published in Issue 5, 2020.

Citation: de Cassan S, Thompson MJ, Perera R, Glasziou PP, Del Mar CB, Heneghan CJ, Hayward G. Corticosteroids as standalone or add-on treatment for sore throat. Cochrane Database of Systematic Reviews 2020, Issue 5. Art. No.: CD008268. DOI: 10.1002/14651858.CD008268.pub3.

Copyright ( 2020 The Cochrane Collaboration. Published by John Wiley \& Sons, Ltd.

\section{A B S T R A C T}

\section{Background}

Sore throat is a common condition associated with a high rate of antibiotic prescriptions, despite limited evidence for the effectiveness of antibiotics. Corticosteroids may improve symptoms of sore throat by reducing inflammation of the upper respiratory tract. This review is an update to our review published in 2012.

\section{Objectives}

To assess the clinical benefit and safety of corticosteroids in reducing the symptoms of sore throat in adults and children.

\section{Search methods}

We searched CENTRAL (Issue 4, 2019), MEDLINE (1966 to 14 May 2019), Embase (1974 to 14 May 2019), the Database of Abstracts of Reviews of Effects (DARE, 2002 to 2015), and the NHS Economic Evaluation Database (inception to 2015). We also searched the World Health Organization International Clinical Trials Registry Platform (WHO ICTRP) and ClinicalTrials.gov.

\section{Selection criteria}

We included randomised controlled trials (RCTs) that compared steroids to either placebo or standard care in adults and children (aged over three years) with sore throat. We excluded studies of hospitalised participants, those with infectious mononucleosis (glandular fever), sore throat following tonsillectomy or intubation, or peritonsillar abscess.

\section{Data collection and analysis}

We used standard methodological procedures expected by Cochrane.

\section{Main results}

We included one new RCT in this update, for a total of nine trials involving 1319 participants (369 children and 950 adults). In eight trials, participants in both corticosteroid and placebo groups received antibiotics; one trial offered delayed prescription of antibiotics based on clinical assessment. Only two trials reported funding sources (government and a university foundation).

In addition to any effect of antibiotics and analgesia, corticosteroids increased the likelihood of complete resolution of pain at 24 hours by 2.40 times (risk ratio (RR) $2.4,95 \%$ confidence interval $(\mathrm{Cl}) 1.29$ to $4.47 ; \mathrm{P}=0.006 ; \mathrm{I}^{2}=67 \%$; high-certainty evidence) and at 48 hours by 1.5 times (RR 1.50, 95\% Cl 1.27 to 1.76; $\mathrm{P}<0.001 ; \mathrm{I}^{2}=0 \%$; high-certainty evidence). Five people need to be treated to prevent one person continuing to experience pain at 24 hours. Corticosteroids also reduced the mean time to onset of pain relief and the mean time to complete resolution of pain by 6 and 11.6 hours, respectively, although significant heterogeneity was present (moderate-certainty evidence). At 24 
hours, pain (assessed by visual analogue scales) was reduced by an additional $10.6 \%$ by corticosteroids (moderate-certainty evidence). No differences were reported in recurrence/relapse rates, days missed from work or school, or adverse events for participants taking corticosteroids compared to placebo. However, the reporting of adverse events was poor, and only two trials included children or reported days missed from work or school. The included studies were assessed as moderate quality evidence, but the small number of included studies has the potential to increase the uncertainty, particularly in terms of applying these results to children.

\section{Authors' conclusions}

Oral or intramuscular corticosteroids, in addition to antibiotics, moderately increased the likelihood of both resolution and improvement of pain in participants with sore throat. Given the limited benefit, further research into the harms and benefits of short courses of steroids is needed to permit informed decision-making.

\section{PLAIN LANGUAGE SUMMARY}

\section{Corticosteroids as stand-alone or add-on treatment for sore throat}

\section{Review question}

Are corticosteroids beneficial for people with sore throat either alone or in addition to other treatment?

\section{Background}

Sore throat is very common. Although most sore throats are caused by viruses, many people with sore throat receive antibiotics, which are not effective in treating viral infections. Overuse of antibiotics contributes to antibiotic resistance in individuals and the community. Sore throats are painful because of inflammation of the lining of the throat. Steroids, or corticosteroids, are medications that can be taken as tablets or injected. They reduce inflammation and help in other airways infections such as croup. Short courses of steroids may be beneficial to treat sore throat.

\section{Search date}

14 May 2019.

\section{Study characteristics}

This is an update of our 2012 review. We added one new trial (565 participants) for a total nine trials involving 1319 participants (369 children, 950 adults). The included trials were conducted in emergency department ( 7 trials) and primary care ( 2 trials) settings in the USA ( 5 trials), and one trial each in Canada, Israel, Turkey, and the UK. Participants received either a single dose of steroids or a single dose of a dummy drug (placebo) ( 7 trials). More than one consecutive daily dose of steroid or placebo was given to one group of participants, whilst the other group received a single dose ( 2 trials). In eight trials all participants also received antibiotics immediately on entry to the study. All trials were published in English.

\section{Study funding sources}

Two studies described funding sources (government and a university foundation).

\section{Key results}

Participants who received corticosteroids were 2.4 times more likely to experience complete resolution of sore throat symptoms by 24 hours than those who received placebo. Corticosteroids improved times to both start symptom relief and to completely resolve symptoms, although trial evidence was not consistent for these outcomes, and effects were modest. Adverse events, recurrence/relapse rates, and days missed from work or school did not differ between corticosteroid and placebo group participants. Sore throats are very common in children, but only two trials reported results for children, and these results were inconsistent, making it difficult to draw conclusions. Further research is therefore needed to examine the benefits of corticosteroids for both reducing antibiotic use in people with severe sore throat, and the benefit for children specifically. Limitations were that only two trials included children and that most trials also gave antibiotics to all participants.

\section{Quality of the evidence}

We assessed the certainty of the evidence as high for complete resolution of pain at 24 and 48 hours, and moderate for mean time to onset of pain relief, mean time to complete resolution of pain, absolute reduction in pain measured by visual analogue scales, adverse events, recurrence/relapse rates, and days missed from work or school. 
SUMMARY OF FINDINGS

\section{Summary of findings 1 . Corticosteroids compared to placebo for sore throat}

\section{Corticosteroids compared to placebo for sore throat}

Patient or population: patients with sore throat

Setting: emergency departments and general practice

Intervention: corticosteroids

Comparison: placebo

\begin{tabular}{|c|c|c|c|c|c|c|}
\hline \multirow[t]{2}{*}{ Outcomes } & \multicolumn{2}{|c|}{ Anticipated absolute effects ${ }^{\star}(95 \% \mathrm{Cl})$} & \multirow{2}{*}{$\begin{array}{l}\text { Relative effect } \\
(95 \% \mathrm{Cl})\end{array}$} & \multirow{2}{*}{$\begin{array}{l}\text { № of partici- } \\
\text { pants } \\
\text { (studies) }\end{array}$} & \multirow{2}{*}{$\begin{array}{l}\text { Certainty of } \\
\text { the evidence } \\
\text { (GRADE) }\end{array}$} & \multirow[t]{2}{*}{ Comments } \\
\hline & Risk with placebo & $\begin{array}{l}\text { Risk with corticos- } \\
\text { teroids }\end{array}$ & & & & \\
\hline \multirow{2}{*}{$\begin{array}{l}\text { Complete resolu- } \\
\text { tion of pain at } 24 \\
\text { hours }\end{array}$} & Study population & & \multirow{2}{*}{$\begin{array}{l}\text { RR } 2.40 \\
\text { (1.29 to } 4.47)\end{array}$} & \multirow{2}{*}{$\begin{array}{l}851 \\
(5 \mathrm{RCTs})\end{array}$} & \multirow{2}{*}{$\begin{array}{l}\oplus \oplus \oplus \oplus \\
\mathrm{HIGH}\end{array}$} & \\
\hline & 158 per 1000 & $\begin{array}{l}379 \text { per } 1000 \\
(204 \text { to } 706)\end{array}$ & & & & \\
\hline \multirow{2}{*}{$\begin{array}{l}\text { Complete resolu- } \\
\text { tion of pain at } 48 \\
\text { hours }\end{array}$} & Study population & & \multirow{2}{*}{$\begin{array}{l}\text { RR } 1.50 \\
\text { (1.27 to } 1.76)\end{array}$} & \multirow{2}{*}{$\begin{array}{l}774 \\
(4 \mathrm{RCTs})\end{array}$} & \multirow{2}{*}{$\begin{array}{l}\oplus \oplus \oplus \oplus \\
\mathrm{HIGH}\end{array}$} & \\
\hline & 327 per 1000 & $\begin{array}{l}491 \text { per } 1000 \\
(416 \text { to } 576)\end{array}$ & & & & \\
\hline $\begin{array}{l}\text { Mean time to on- } \\
\text { set of pain relief }\end{array}$ & $\begin{array}{l}\text { The mean time to onset } \\
\text { of pain relief was } 17.7 \\
\text { (hours). }\end{array}$ & $\begin{array}{l}\text { MD } 5.96 \text { lower } \\
\text { (8.75 lower to } 3.17 \text { low- } \\
\text { er) }\end{array}$ & - & $\begin{array}{l}840 \\
(7 \mathrm{RCTs})\end{array}$ & $\begin{array}{l}\oplus \oplus \oplus \ominus \\
\text { MODERATE a }\end{array}$ & $\begin{array}{l}\text { Based on a sensitivity analysis the } \\
\text { source of heterogeneity is unclear. }\end{array}$ \\
\hline $\begin{array}{l}\text { Absolute reduc- } \\
\text { tion in pain mea- } \\
\text { sured by VAS }\end{array}$ & $\begin{array}{l}\text { The mean absolute re- } \\
\text { duction in pain mea- } \\
\text { sured by VAS at } 24 \text { hours } \\
\text { was } 3.7 \text {. }\end{array}$ & $\begin{array}{l}\text { MD } 1.06 \text { higher } \\
(0.21 \text { higher to } 1.92 \\
\text { higher) }\end{array}$ & - & $\begin{array}{l}1004 \\
\text { (7 RCTs) }\end{array}$ & $\begin{array}{l}\oplus \oplus \oplus \odot \\
\text { MODERATE c }\end{array}$ & $\begin{array}{l}\text { Different visual analogue scales were } \\
\text { used in the included studies. Based on } \\
\text { a sensitivity analysis the source of het- } \\
\text { erogeneity is unclear. }\end{array}$ \\
\hline \multirow[t]{2}{*}{ Adverse events } & Study population & & \multirow{2}{*}{$\begin{array}{l}\text { RR } 1.08 \\
\text { (0.31 to } 3.77)\end{array}$} & \multirow{2}{*}{$\begin{array}{l}690 \\
(2 \mathrm{RCTs})\end{array}$} & \multirow{2}{*}{$\begin{array}{l}\oplus \oplus \oplus \ominus \\
\text { MODERATE } d\end{array}$} & \multirow{2}{*}{$\begin{array}{l}\text { Only } 2 \text { studies included with total } \\
\text { number of cases }<345 \text {. }\end{array}$} \\
\hline & 14 per 1000 & 16 per 1000 & & & & \\
\hline
\end{tabular}




\begin{tabular}{|c|c|c|c|c|c|c|c|}
\hline \multirow{3}{*}{\multicolumn{2}{|c|}{ 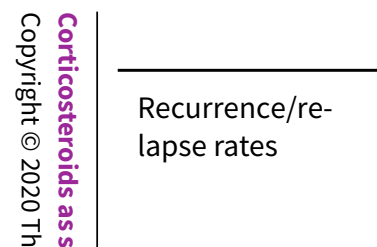 }} & \multicolumn{2}{|r|}{ (4 to 55$)$} & \multirow{2}{*}{$\begin{array}{l}\text { RR } 0.52 \\
(0.16 \text { to } 1.73)\end{array}$} & \multirow{3}{*}{$\begin{array}{l}353 \\
(3 \mathrm{RCTS})\end{array}$} & \multirow{3}{*}{$\begin{array}{l}\oplus \oplus \oplus \ominus \\
\text { MODERATE e }\end{array}$} & \multirow{3}{*}{$\begin{array}{l}\text { Only } 2 \text { studies included with total } \\
\text { number of cases }<200 \text {. }\end{array}$} \\
\hline & & \multicolumn{2}{|l|}{ Study population } & & & & \\
\hline & & 75 per 1000 & $\begin{array}{l}39 \text { per } 1000 \\
(12 \text { to } 129)\end{array}$ & & & & \\
\hline 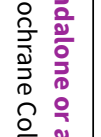 & $\begin{array}{l}\text { Days missed from } \\
\text { work or school }\end{array}$ & $\begin{array}{l}\text { The mean number of } \\
\text { days missed from work } \\
\text { or school was 3.3. }\end{array}$ & $\begin{array}{l}\text { MD } 0.28 \text { lower } \\
\text { ( } 0.84 \text { lower to } 0.28 \\
\text { higher) }\end{array}$ & - & $\begin{array}{l}405 \\
\text { (2 RCTs) }\end{array}$ & $\begin{array}{l}\oplus \oplus \oplus \ominus \\
\text { MODERATE } f\end{array}$ & $\begin{array}{l}\text { Only } 2 \text { studies included with total } \\
\text { number of cases }<250 \text {. }\end{array}$ \\
\hline
\end{tabular}

${ }^{\star}$ The risk in the intervention group (and its $95 \%$ confidence interval) is based on the assumed risk in the comparison group and the relative effect of the intervention (and its $95 \% \mathrm{Cl})$.

CI: confidence interval; MD: mean difference; RCT: randomised controlled trial; RR: risk ratio; VAS: visual analogue scale

\section{GRADE Working Group grades of evidence}

High certainty: We are very confident that the true effect lies close to that of the estimate of the effect.

Moderate certainty: We are moderately confident in the effect estimate: the true effect is likely to be close to the estimate of the effect, but there is a possibility that it is substantially different.

Low certainty: Our confidence in the effect estimate is limited: the true effect may be substantially different from the estimate of the effect.

Very low certainty: We have very little confidence in the effect estimate: the true effect is likely to be substantially different from the estimate of effect.

a-cDowngraded from high- to moderate-certainty evidence due to substantial heterogeneity.

d-fDowngraded from high- to moderate-certainty evidence due to imprecision. 


\section{B A C K G R O U N D}

\section{Description of the condition}

Sore throat is a very common reason for seeking medical care, accounting for approximately nine consultations for every 100 patients registered with a general practitioner in the UK (Gulliford 2009). In the USA, $1 \%$ to $2 \%$ of ambulatory care visits are related to sore throats (Schappert 2008). 'Sore throat' is a term that can refer to a patient's complaint of pain in the throat due to an infection, but also includes pathological conditions such as tonsillitis or pharyngitis. Many sore throats are caused by viral infections such as rhinovirus, coronavirus, and adenovirus. The main bacterial pathogen is group A beta-haemolytic streptococcus (GABHS), found in approximately $10 \%$ of sore throats in adults and $15 \%$ to $30 \%$ of those in children (Bisno 2001; Linder 2005). Although antibiotics offer only a small benefit for sore throat (Spinks 2013), the rate of antibiotic prescribing for this condition remains high, with an estimated rate of $60 \%$ of UK consultations in 2011 (Gulliford 2014). This may be due in part to attempts by clinicians to reduce symptoms in patients with sore throat and also to reduce the risk of known complications of streptococcal throat infection such as peritonsillar abscess, rheumatic fever, and glomerulonephritis. However, the incidence of these complications is currently very low in high-income countries. For example, hospital admission for peritonsillar abscess occurs in fewer than 4 per 100,000 people, and the effects of antibiotics overall in patients with sore throats is small, with a number needed to treat for an additional beneficial outcome of 21 to prevent one sore throat at week one (Howie 1985; Little 2002; NICE 2008; Petersen 2007; Sharland 2005; Spinks 2013). Furthermore, unnecessary antibiotic use contributes to the development of antimicrobial resistance (Costelloe 2010; SMAC 1998).

\section{Description of the intervention}

Corticosteroids are a group of steroid hormones that are secreted naturally by the adrenal cortex and are also synthetically produced. They are hormones that are involved in a large range of physiological systems in the human body, particularly those related to inflammation and immune response. Synthetic corticosteroids are widely used in clinical practice in topical, oral, and parenteral forms. The intervention examined in this review was the use of corticosteroids administered locally (e.g. sprays into the throat) or systemically (by oral or parenteral administration) to participants with sore throats.

\section{How the intervention might work}

The discomfort experienced by people with sore throat is due to inflammation in the oropharyngeal mucosa. This results in pain, and particularly pain with swallowing saliva or ingesting food or drink. Reducing the level of inflammation could therefore lead to fewer symptoms. Analgesics currently used for sore throat include topical agents with mild local anaesthetic properties, as well as oral agents such as non-steroidal anti-inflammatory drugs. Corticosteroids are widely used to reduce inflammation in many conditions, both locally (e.g. topical corticosteroids for eczema, steroid joint injections for inflamed joints), as well as systemically (e.g. oral steroids for rheumatoid arthritis). Moreover, corticosteroids decrease inflammation in the respiratory tract epithelium (Mygind 2001), and improve symptoms and other outcomes in other upper respiratory tract infections such as acute sinusitis, Zalmanovici Trestioreanu 2013, and viral croup (Gates 2018). They may also provide short-term relief from the symptoms of sore throat in glandular fever (infectious mononucleosis) (Rezk 2015). The question we addressed was whether corticosteroids offer relief for symptoms in adults and children with sore throats.

\section{Why it is important to do this review}

There are currently few therapeutic options for managing sore throats in adults and children. There is wide consensus that antibiotics are overused for treating sore throat in primary care and contribute to growing antibiotic resistance both in the UK and other countries (Harris 2016; NICE 2008; NICE 2018). Oral and topical analgesics are often recommended or prescribed for sore throat, with unclear benefit (NICE 2008; NICE 2018). If corticosteroids provided significant symptomatic benefit in people with sore throat, they could potentially fill this therapeutic vacuum. If corticosteroids reduce symptoms without adverse effects they might be used to reduce the demand for or use of antibiotics for this condition.

Although corticosteroids are widely used in clinical practice, they can cause side effects. It is therefore important to determine how frequently these occur in treating patients with sore throat and whether they are outweighed by any benefits. This review attempted to answer this question for sore throat in adults and children.

\section{O B JECT IVES}

To assess the clinical benefit and safety of corticosteroids in reducing the symptoms of sore throat in adults and children.

\section{METHODS}

\section{Criteria for considering studies for this review}

\section{Types of studies}

Randomised controlled trials (RCTs) comparing corticosteroids to placebo or to standard clinical management.

\section{Types of participants}

We included adults and children (aged over three years) with sore throat. Specifically, sore throat includes the following.

1. Clinical signs of acute tonsillitis - inflammation of the tonsils.

2. Pharyngitis - inflammation of the oropharynx.

3. Clinical syndrome of sore throat (painful throat, odynophagia).

We excluded studies of hospitalised participants but included studies examining outpatients seen in the emergency department setting. We excluded studies of participants with glandular fever, sore throat following tonsillectomy or intubation, or peritonsillar abscess.

\section{Types of interventions}

We included studies that used corticosteroids versus standard clinical care or placebo in the control group. We included all routes and types of corticosteroid administration. We included trials reporting combined interventions if they allowed a direct comparison between corticosteroids and usual care. 


\section{Types of outcome measures}

\section{Primary outcomes}

1. Complete resolution of pain at 24 and 48 hours.

2. Mean time to onset of pain relief.

3. Mean time to complete resolution of pain.

\section{Secondary outcomes}

1. Absolute reduction in pain measured by visual analogue scales.

2. Adverse events.

3. Recurrence/relapse rates.

4. Days missed from school or work.

\section{Search methods for identification of studies}

\section{Electronic searches}

For this update we searched CENTRAL (2019, Issue 4), which includes the Cochrane Acute Respiratory Infections (ARI) Group's Specialised Register, MEDLINE (June 2014 to 14 May 2019), and Embase (June 2014 to 14 May 2019). NHS Economic Evaluation Database and Database of Abstracts of Reviews of Effects (DARE) ceased adding records after 31 March 2015 and have now been searched completely for this review.

We previously searched CENTRAL (2012, Issue 5), MEDLINE (1966 to June 2012), and Embase (1974 to June 2012).

We combined our search strategy with the Cochrane Highly Sensitive Search Strategy for identifying randomised trials in MEDLINE: sensitivity- and precision-maximising version (2008 revision), Ovid format (Appendix 1) (Lefebvre 2011). We adapted the search strategy to search Embase (Appendix 2).

\section{Searching other resources}

To increase the yield of relevant studies, we searched the references of all studies identified by screening. We looked for ongoing trials registered with the World Health Organization International Clinical Trials Registry Platform (WHO ICTRP) (apps.who.int/trialsearch/) (searched 8 June 2019). CENTRAL (2019, Issue 4) also includes records from the WHO ICTRP. We also searched the US National Institutes of Health Ongoing Trials Register ClinicalTrials.gov (clinicaltrials.gov/) (8 June 2019). There were no language or publication restrictions.

\section{Data collection and analysis}

\section{Selection of studies}

Two review authors (GH, MT) independently screened the titles and abstracts identified from the electronic searches for our 2012 review (Hayward 2012). We obtained the full-text study reports of potentially eligible studies, which we assessed for relevance. Any disagreements were resolved by discussion with a third review author $(\mathrm{CH})$.

For this update, three review authors (GH, CDM, SdC) independently screened the titles and abstracts identified by the searches. We obtained the full-text study reports of potentially eligible studies to determine those that met the inclusion criteria, and identified and recorded reasons for exclusion of ineligible studies. Any disagreements were resolved by discussion with a third review author $(\mathrm{CH})$. We identified and excluded duplicates and collated multiple reports of the same study so that each study, rather than each report, was the unit of interest in the review. We recorded the selection process in sufficient detail to complete a PRISMA flow diagram (Figure 1) and Characteristics of excluded studies table (Moher 2009). We did not impose any language restrictions. 
Figure 1. Study flow diagram (2019 update)

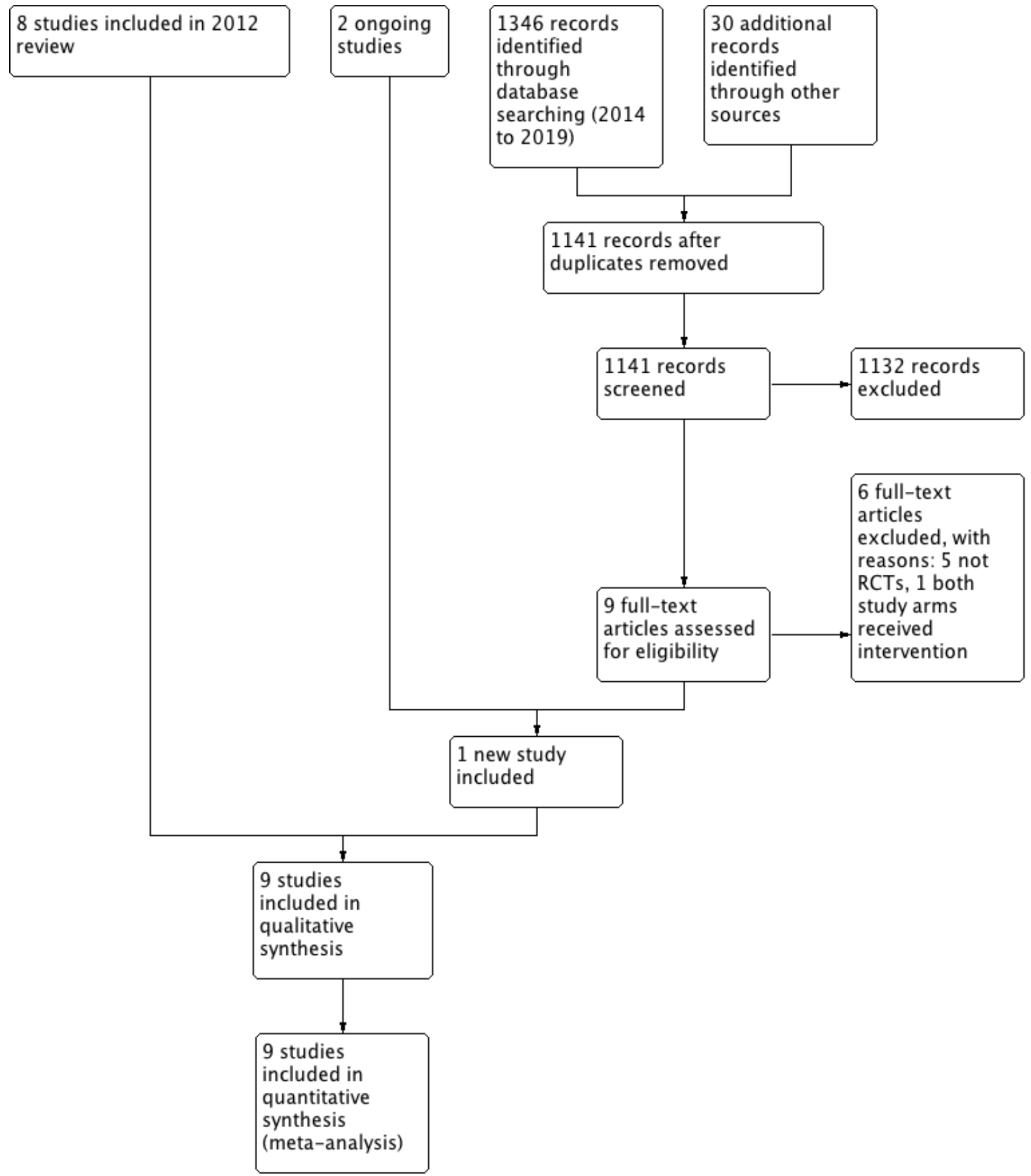

\section{Data extraction and management}

Two review authors (GH, MT) independently extracted data from the included trials for our 2012 review (Hayward 2012). For this update, two review authors (CDM, PG) independently extracted data from the included trials. Any disagreements were documented and resolved by discussion with a third review author $(\mathrm{CH})$. A statistician (RP) independently reviewed all data extracted from the original publications to verify the certainty of methods and analyses used. We selected the data closest to a single-dose regimen as our conservative strategy in those studies using different dosing regimens. Where studies reported results from both oral and intramuscular corticosteroid use, we used oral data for our overall analyses and intramuscular data in appropriate subgroup analyses. We requested additional data from trial authors 
where necessary, and extracted data from graphs using Grab It! XP in Microsoft Excel (Grab It! XP 2010).

\section{Assessment of risk of bias in included studies}

Two review authors (GH, MT) independently assessed risk of bias for each study using the criteria outlined in the Cochrane Handbook for Systematic Reviews of Interventions (Higgins 2011), for our 2012 review (Hayward 2012). This was undertaken by two review authors (PG, CDM) for this update. In both versions, any disagreements were resolved by discussion with a third review author $(\mathrm{CH})$. We assess risk of bias according to the following domains.

1. Random sequence generation.

2. Allocation concealment.

3. Blinding of participants and personnel.

4. Blinding of outcome assessment.

5. Incomplete outcome data.

6. Selective outcome reporting.

7. Other bias.

We graded each potential source of bias as high, low, or unclear and provided quotes from the study report together with a justification for our judgement in the 'Risk of bias' tables. We summarised the 'Risk of bias' judgements across different studies for each of the domains listed. We considered blinding separately for different key outcomes where necessary. Where information on risk of bias related to unpublished data or correspondence with a trialist, we noted this in the 'Risk of bias' tables.

When considering treatment effects, we took into account the risk of bias for the studies that contributed to that outcome.

\section{Assessment of bias in conducting the systematic review}

We conducted the review according to a published protocol and reported deviations from it in the Differences between protocol and review section.

\section{Measures of treatment effect}

We expressed dichotomous outcomes as risk ratios (RR) and calculated $95 \%$ confidence intervals (Cls). We expressed continuous variables as a mean difference (MD) if reported on the same scale or as standardised mean difference (SMD) if reported using different continuous scales and calculated 95\% Cls. We defined pain resolution as the primary outcome due to its clinical relevance to participants. Given the frequency of this outcome within studies, relative risks were used to summarise the observed effect.

\section{Unit of analysis issues}

The unit of analysis for each outcome was the individual study participant.

\section{Dealing with missing data}

We considered that incomplete outcome data had been addressed if more than $80 \%$ of participants were included in the analysis. All included trials satisfied this criterion for at least some outcome measures. Where data were missing (e.g. change from baseline data where baseline and endpoint values were provided), we calculated this using the formula suggested in the Cochrane Handbook for Systematic Reviews of Interventions (Higgins 2011).

\section{Assessment of heterogeneity}

We used the $1^{2}$ statistic to quantify the level of statistical heterogeneity for each outcome (Higgins 2003). We considered possible explanations where substantial heterogeneity $\left(I^{2}>50 \%\right)$ was detected, or considered not combining the results and presenting a descriptive analysis instead.

\section{Assessment of reporting biases}

We compared data previously published as an abstract with the full paper where possible. We assessed the extent to which common outcomes were reported by each paper and looked for incomplete reporting of outcomes.

\section{Data synthesis}

We planned to pool data from studies judged to be clinically homogeneous using Review Manager 5 software (Review Manager 2014). If more than one study provided usable data in any single comparison, we performed a meta-analysis. Given that our inclusion criteria allowed for studies of all routes and types of corticosteroid administration, we used a random-effects model to obtain pooled estimates.

\section{GRADE and 'Summary of findings' table}

We created Summary of findings 1 using the following outcomes: complete resolution of pain at 24 hours, complete resolution of pain at 48 hours, mean time to onset of pain relief, mean time to complete resolution of pain, mean absolute reduction in pain measured by visual analogue scales, adverse events, recurrence/relapse rates, and number of days missed from work or school. We used the five GRADE considerations (study limitations, consistency of effect, imprecision, indirectness, and publication bias) to assess the certainty of the evidence as it related to the studies which contributed data to the meta-analyses for the prespecified outcomes (Atkins 2004). We used the methods and recommendations described in Section 8.5 and Chapter 12 of the Cochrane Handbook for Systematic Reviews of Interventions (Higgins 2011), employing GRADEpro GDT software (GRADEpro GDT 2015). We justified all decisions to down- or upgrade the certainty of the evidence in footnotes, and made comments to aid readers' understanding of the review where necessary.

\section{Subgroup analysis and investigation of heterogeneity}

We performed subgroup analyses for the following groups.
1. Children/adults
2. Proven bacterial pathogen
3. Route of corticosteroid administration
4. Presence/absence of exudate
5. Severity of sore throat

We performed subgroup analyses only where each subgroup contained two or more studies, because analyses of small subgroups often produce misleading results.

\section{Sensitivity analysis}

Where we found heterogeneity, we explored the causes, in particular by examining the characteristics (methodological and clinical) of the included trials. We conducted a sensitivity analysis to understand the impact of any differences on the results. 


\section{RESULTS}

\section{Description of studies}

\section{Results of the search}

Our searches identified 1376 potentially eligible records for this update. We removed 235 duplicate records and assessed 1141 records by title and abstract, of which 1132 records were excluded as ineligible. We obtained 9 full-text articles for assessment and excluded 8 (5 not RCTs, 1 wrong intervention regimen, and 2 ongoing studies). We included one new RCT in this update (Hayward 2017; Figure 1), which we added to the eight legacy studies from our 2012 review (Hayward 2012), for a total of nine included studies in this update (Bulloch 2003; Hayward 2017; Kiderman 2005; Marvez-Valls 1998; Niland 2006; O'Brien 1993; Olympia 2005; Tasar 2008; Wei 2002). We consulted Stovold 2014 to compile results of all literature searches.

\section{Included studies}

\section{Participants}

We included nine studies that reported on a total of 1319 participants (369 participants aged 5 to 21 years and 950 participants aged 12 to 65 years): 409 (31\%) had exudative sore throat, and 393 (30\%) were group A beta-haemolytic streptococcus (GABHS)-positive. Three trials included only adult participants (Hayward 2017; Kiderman 2005; Tasar 2008); two trials included only children (Bulloch 2003; Olympia 2005) (age range 5 to 18 years), whilst the remainder included both age groups.

Participants were recruited from emergency department and general practice settings in five countries: the USA (Marvez-Valls 1998; Niland 2006; O'Brien 1993; Olympia 2005; Wei 2002), Canada (Bulloch 2003), Israel (Kiderman 2005), Turkey (Tasar 2008), and the UK (Hayward 2017).

\section{Interventions}

Antibiotics were administered to both corticosteroid and placebo group participants in all of the included trials. Corticosteroids used included betamethasone $2 \mathrm{~mL}$ (estimated dose $8 \mathrm{mg}$ ) (MarvezValls 1998), dexamethasone (up to $10 \mathrm{mg}$ ) (Bulloch 2003; Hayward 2017; Niland 2006; O'Brien 1993; Olympia 2005; Tasar 2008; Wei 2002), or prednisone $60 \mathrm{mg}$ (Kiderman 2005). Corticosteroids were administered by intramuscular injection (Marvez-Valls 1998; O'Brien 1993; Tasar 2008), orally (Bulloch 2003; Hayward 2017; Kiderman 2005; Niland 2006; Olympia 2005), or both (Wei 2002). Seven trials used a single dose of corticosteroids (Bulloch 2003; Hayward 2017; Marvez-Valls 1998; O'Brien 1993; Olympia 2005; Tasar 2008; Wei 2002), and two trials prescribed more than one dose of corticosteroids to a subgroup of participants (Kiderman 2005; Niland 2006).

\section{Outcomes}

Outcome measures included complete resolution of pain at 24 hours, Hayward 2017; Kiderman 2005; Niland 2006; Tasar 2008; Wei 2002, and 48 hours (Hayward 2017; Kiderman 2005; Niland
2006; Tasar 2008), mean time to onset of pain relief (Bulloch 2003; Hayward 2017; Marvez-Valls 1998; O'Brien 1993; Olympia 2005; Tasar 2008; Wei 2002), mean time to complete resolution of pain (Bulloch 2003; Hayward 2017; Marvez-Valls 1998; O'Brien 1993; Olympia 2005; Tasar 2008), absolute reduction in pain measured by visual analogue scale (Bulloch 2003; Hayward 2017; Kiderman 2005; Marvez-Valls 1998; O'Brien 1993; Olympia 2005; Wei 2002), adverse events (Bulloch 2003; Hayward 2017; O'Brien 1993; Olympia 2005; Tasar 2008), recurrence/relapse rates (Bulloch 2003; Kiderman 2005; Niland 2006), and days missed from school or work (Hayward 2017; Marvez-Valls 1998). See Summary of findings 1.

Seven trials prescribed antibiotics to both intervention and placebo arm participants and permitted simple analgesia. Only one trial prescribed antibiotics to those testing positive for GABHS on direct antigen testing (Bulloch 2003). One trial prescribed no immediate antibiotics but allowed clinicians to decide whether to offer a delayed antibiotic prescription (Hayward 2017). Analgesia use was recorded in five trials, and in all cases, no significant differences were reported (Hayward 2017; Niland 2006; O'Brien 1993; Olympia 2005; Wei 2002). Two trials restricted analgesia to paracetamol for 24 or 72 hours, recording no difference in use, Wei 2002, and not reporting usage, Tasar 2008, respectively. Four trials reported outcomes for bacterial pathogen-positive and -negative participants separately (Bulloch 2003; Marvez-Valls 1998; Olympia 2005; Wei 2002).

\section{Sources of funding}

Only two trials reported funding sources (Bulloch 2003; Hayward 2017); these trials were supported by a university foundation fund and a UK government source, respectively.

\section{Excluded studies}

We previously excluded four clinical studies. One was an abstract duplicating a trial reported elsewhere (Olympia 2005), and one did not include a placebo comparison group (Marvez-Valls 2002). One study was conducted in hospitalised participants (Hahn 1951), and one did not randomise participants or use a placebo (confirmed by personal communication), and was thus not considered to be an RCT (Ahn 2003).

For this review update we excluded one clinical study that administered steroids to both study arms (Chen 2018). We excluded a further five studies after full-text review because they were all systematic reviews including trials reported on in this review (Armstrong 2018; Chenot 2018; Hristea 2013; Shaughnessy 2018; Welch 2014).

\section{Ongoing studies}

We identified two ongoing studies for which results are pending (ACTRN12618000017224; ACTRN12618000847213).

\section{Risk of bias in included studies}

We assessed risk of bias for all included studies as low overall. A summary of our assessments is shown in Figure 2. 
Figure 2. 'Risk of bias' summary: review authors' judgements about each risk of bias item for each included study

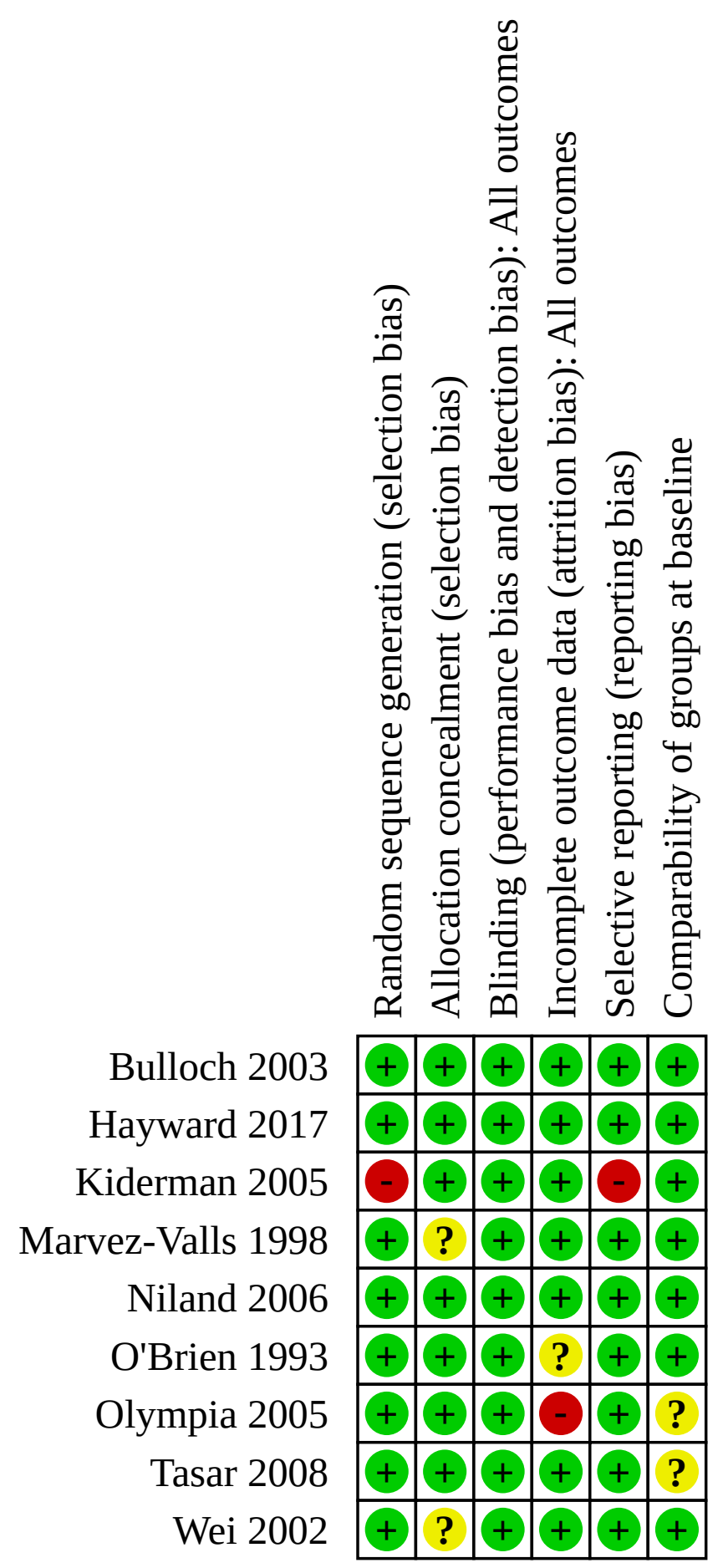




\section{Allocation}

We judged there to be a low risk of selection bias related to allocation concealment in seven studies (Bulloch 2003; Hayward 2017; Kiderman 2005; Niland 2006; O'Brien 1993; Olympia 2005; Tasar 2008). Two included studies did not report methods of allocation concealment, although both reported that trials were double-blinded and placebo-controlled (Marvez-Valls 1998; Wei 2002).

We judged there to be a low risk of selection bias related to randomisation in eight studies (Bulloch 2003; Hayward 2017; Marvez-Valls 1998; Niland 2006; O'Brien 1993; Olympia 2005; Tasar 2008; Wei 2002). One trial employed a random number table generated using an electronic spreadsheet to prepare treatment packages, but then used chance selection to assign participants to placebo or steroid arms (Kiderman 2005); we considered the risk of bias in this case to be high.

\section{Blinding}

We judged all included trials as at low risk of bias for this domain, as they all used a double-blind design. However, only four studies explicitly stated that their outcome assessors were blinded to the intervention (Bulloch 2003; Hayward 2017; Kiderman 2005; MarvezValls 1998).

\section{Incomplete outcome data}

Olympia 2005 reported the highest number of participants lost to follow-up (125/150 participants provided outcome data) and was assessed at high risk of bias for this domain. Olympia 2005 aimed to obtain daily follow-up assessment until complete resolution of sore throat and excluded any child who did not meet this criterion, which is a more strict criterion than used by other trials (Bulloch 2003; Wei 2002), and accounted for over $70 \%$ of those lost to follow-up. We assessed O'Brien 1993 at unclear risk of attrition bias because for outcomes at 24 hours, only $7 / 58$ participants were lost to follow-up, which was judged as low risk, but for the outcome of time to complete pain resolution, 32/58 participants were lost to follow-up, which was judged as high risk. Three studies reported no losses to follow-up and were assessed as low risk of bias (Kiderman 2005; Marvez-Valls 1998; Tasar 2008). Hayward 2017 and Niland 2006 were assessed as low risk with $6 \%$ and $7 \%$ lost to follow-up, respectively.

\section{Selective reporting}

All of the included studies measured appropriate and common outcomes and reported all outcomes assessed. In the only paper to have previously published an abstract on the research, no additional outcomes were reported (Olympia 2005). Participants in one trial were randomised to either a one-day course or a two-day course of either prednisolone or placebo, but the study authors then failed to report data for these two groups separately, despite reporting in the text that prednisolone had a significantly greater effect in the two-day group compared to the one-day group (Kiderman 2005); we assessed this study as at high risk of reporting bias.

\section{Other potential sources of bias}

We identified no other sources of bias in the included trials.

\section{Effects of interventions}

See: Summary of findings 1 Corticosteroids compared to placebo for sore throat

\section{Primary outcomes}

\section{Complete resolution of pain at 24 and 48 hours}

Five trials reported resolution of pain at 24 hours (Hayward 2017; Kiderman 2005; Niland 2006; Tasar 2008; Wei 2002), and four at 48 hours (Hayward 2017; Kiderman 2005; Niland 2006; Tasar 2008). At 24 hours, participants treated with corticosteroids were 2.40 times as likely to experience complete resolution of pain (risk ratio (RR) 2.40, 95\% confidence interval $(\mathrm{Cl}) 1.29$ to $4.47 ; \mathrm{P}=0.006 ; \mathrm{I}^{2}=67 \%$; Analysis 1.1; Figure 3). The number needed to treat for an additional beneficial outcome (NNTB) was 4.8 ( $95 \% \mathrm{Cl} 2.85$ to 14.28$)$. Subgroup analysis of oral versus intramuscular drug administration routes revealed a significant benefit for both, with a greater effect size for the intramuscular route, although the test for subgroup differences did not reach significance (oral: RR $1.88,95 \% \mathrm{Cl} 1.13$ to 3.14; intramuscular: RR $4.59,95 \% \mathrm{Cl} 1.62$ to 13.03 ; Analysis 1.2; Figure 4). No other subgroup comparisons were possible. The likelihood of complete resolution of pain at 48 hours was 1.5 times greater in the corticosteroid group (RR $1.5,95 \% \mathrm{Cl} 1.27$ to $1.76 ; \mathrm{P}<0.001 ; \mathrm{I}^{2}=$ $0 \%$; Analysis 1.3; Figure 5). The NNTB was 4.1 ( $95 \% \mathrm{CI} 2.4$ to 16.7). No other subgroup comparisons were possible. We assessed the evidence for these outcomes as of high certainty.

Figure 3. Forest plot of comparison: 1 Corticosteroids versus placebo, outcome: 1.1 Complete resolution of pain at 24 hours

\begin{tabular}{|c|c|c|c|c|c|c|c|c|c|}
\hline \multirow{3}{*}{$\begin{array}{l}\text { Study or Subgroup } \\
\text { Tasar } 2008\end{array}$} & \multicolumn{2}{|c|}{ Corticosteroid } & \multicolumn{2}{|c|}{ Placebo } & \multirow[b]{2}{*}{ Weight } & \multirow{2}{*}{$\begin{array}{c}\text { Risk Ratio } \\
\text { M-H, Random, 95\% CI }\end{array}$} & \multirow{2}{*}{\multicolumn{2}{|c|}{$\begin{array}{c}\text { Risk Ratio } \\
\text { M-H, Random, 95\% CI }\end{array}$}} & \\
\hline & Events & Total & Events & Total & & & & & \\
\hline & 13 & 31 & 2 & 42 & $12.2 \%$ & $8.81[2.14,36.23]$ & & - & \\
\hline Wei 2002 & 12 & 41 & 4 & 36 & $17.2 \%$ & $2.63[0.93,7.45]$ & & - & \\
\hline Kiderman 2005 & 17 & 40 & 4 & 39 & $17.9 \%$ & $4.14[1.53,11.22]$ & & 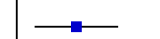 & \\
\hline Niland 2006 & 12 & 27 & 8 & 30 & $22.7 \%$ & $1.67[0.80,3.45]$ & & & \\
\hline Hayward 2017 & 65 & 288 & 49 & 277 & $30.1 \%$ & $1.28[0.92,1.78]$ & & 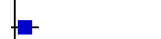 & \\
\hline Total (95\% CI) & & 427 & & 424 & $100.0 \%$ & $2.40[1.29,4.47]$ & & & \\
\hline Total events: & 119 & & 67 & & & & & & \\
\hline \multicolumn{7}{|c|}{ Heterogeneity: $\mathrm{Tau}^{2}=0.31 ; \mathrm{Chi}^{2}=12.05, \mathrm{df}=4(\mathrm{P}=0.02) ; \mathrm{I}^{2}=67 \%$} & 0.01 & 10 & 100 \\
\hline \multicolumn{6}{|c|}{ Test for overall effect: $\mathrm{Z}=2.75(\mathrm{P}=0.006)$} & & Favours placebo & Favours & ticosteroid \\
\hline
\end{tabular}


Figure 4. Forest plot of comparison: 1 Corticosteroids versus placebo, outcome: 1.2 Complete resolution of pain at 24 hours: route of corticosteroid administration

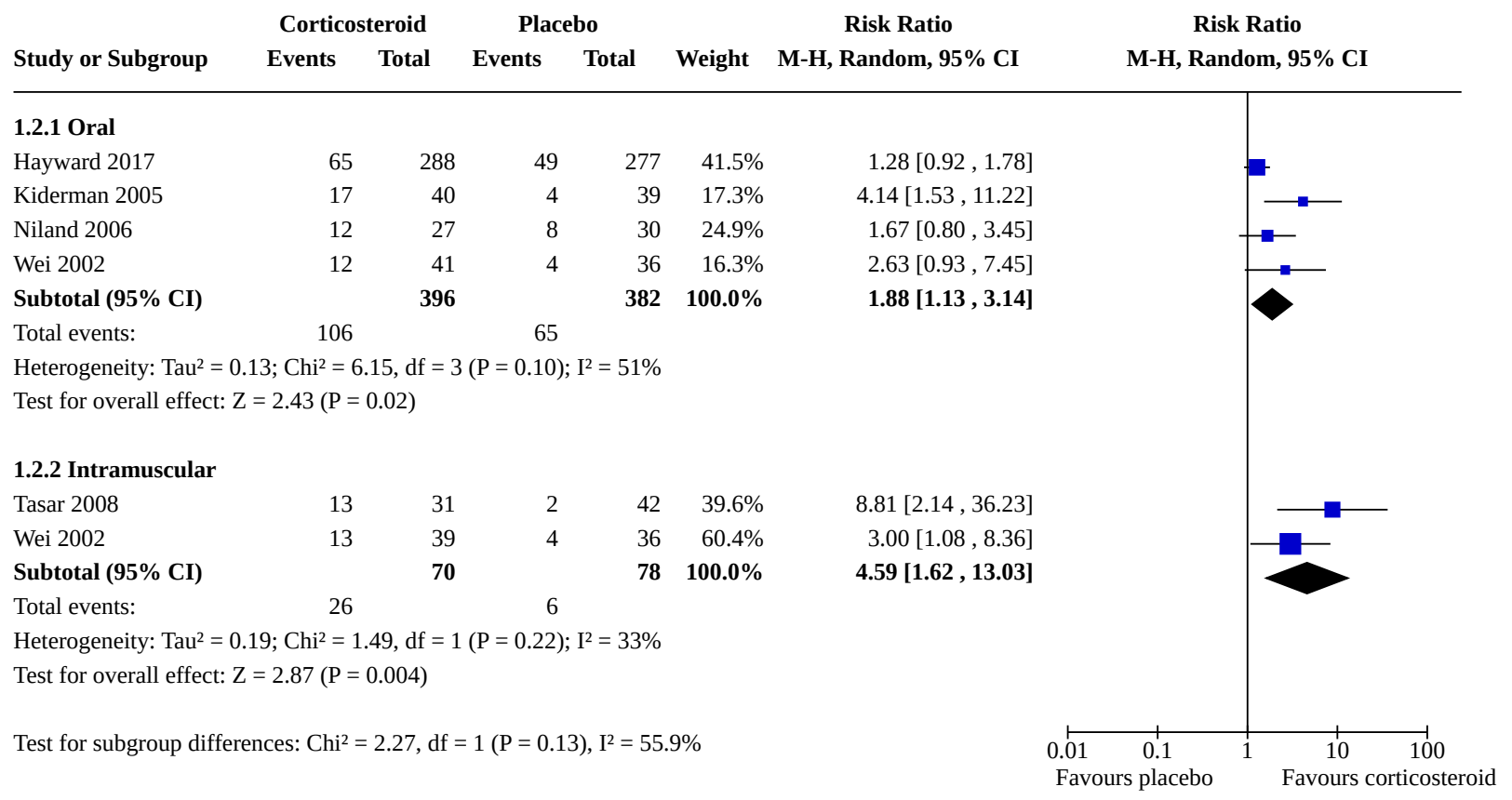

Figure 5. Forest plot of comparison: 1 Corticosteroids versus placebo, outcome: 1.3 Complete resolution of pain at 48 hours

\begin{tabular}{|c|c|c|c|c|c|c|c|c|}
\hline \multirow{3}{*}{$\begin{array}{l}\text { Study or Subgroup } \\
\text { Hayward } 2017\end{array}$} & \multicolumn{2}{|c|}{ Corticosteroid } & \multicolumn{2}{|c|}{ Placebo } & \multirow[b]{2}{*}{ Weight } & \multirow{2}{*}{$\begin{array}{c}\text { Risk Ratio } \\
\text { M-H, Random, 95\% CI }\end{array}$} & \multirow{2}{*}{\multicolumn{2}{|c|}{$\begin{array}{c}\text { Risk Ratio } \\
\text { M-H, Random, 95\% CI }\end{array}$}} \\
\hline & Events & Total & Events & Total & & & & \\
\hline & 102 & 288 & 75 & 277 & $42.1 \%$ & $1.31[1.02,1.68]$ & & $\rightarrow$ \\
\hline Kiderman 2005 & 23 & 40 & 13 & 39 & $9.7 \%$ & $1.73[1.03,2.89]$ & & \\
\hline Niland 2006 & 22 & 27 & 17 & 30 & $19.9 \%$ & $1.44[1.00,2.06]$ & & \\
\hline Tasar 2008 & 29 & 31 & 22 & 42 & $28.3 \%$ & $1.79[1.32,2.42]$ & & 1 \\
\hline Total (95\% CI) & & 386 & & 388 & $100.0 \%$ & $1.50[1.27,1.76]$ & & \\
\hline Total events: & 176 & & 127 & & & & & \\
\hline \multicolumn{7}{|c|}{ Heterogeneity: $\mathrm{Tau}^{2}=0.00 ; \mathrm{Chi}^{2}=2.98, \mathrm{df}=3(\mathrm{P}=0.39) ; \mathrm{I}^{2}=0 \%$} & $0.5 \quad 0.7$ & 1.52 \\
\hline \multicolumn{7}{|c|}{ Test for overall effect: $\mathrm{Z}=4.89(\mathrm{P}<0.00001)$} & Favours placebo & Favours c \\
\hline
\end{tabular}

\section{Mean time to onset of pain relief}

In a pooled analysis of seven trials (Bulloch 2003; Hayward 2017; Marvez-Valls 1998; O'Brien 1993; Olympia 2005; Tasar 2008; Wei 2002), the mean time to onset of pain relief was 6 hours earlier in participants taking corticosteroids compared to placebo (mean difference (MD) $-5.96,95 \% \mathrm{Cl}-8.75$ to -3.17 ; $\mathrm{P}<0.001 ; \mathrm{I}^{2}=69 \%$; Analysis 1.4; Figure 6). As high heterogeneity was evident in this analysis, we performed a sensitivity analysis that excluded each trial in turn (leave-one-out method). This demonstrated a range of mean difference from 4.95 to 6.78 hours with no loss of significance. A number of subgroup analyses were possible for this outcome. In participants with bacterial pathogen-positive sore throat (Analysis
1.5), exudative sore throat (Analysis 1.6), or severe sore throat (Analysis 1.7), the size and direction of effect was greater than trials where fewer than $50 \%$ of participants had exudate, trials that did not select for severe sore throat, or in participants amongst whom bacterial pathogens were not detected. However, in no case did the test for subgroup differences reach significance. Analysis of intramuscular versus oral routes of administration showed a non-significant trend towards a greater effect with intramuscular administration (Analysis 1.8), but both subgroups showed high heterogeneity. We assessed the evidence for this outcome as of moderate certainty. It should be noted that only two trials included children, and a subgroup analysis was not possible for this cohort. 
Figure 6. Forest plot of comparison: 1 Corticosteroids versus placebo, outcome: 1.4 Mean time to onset of pain relief

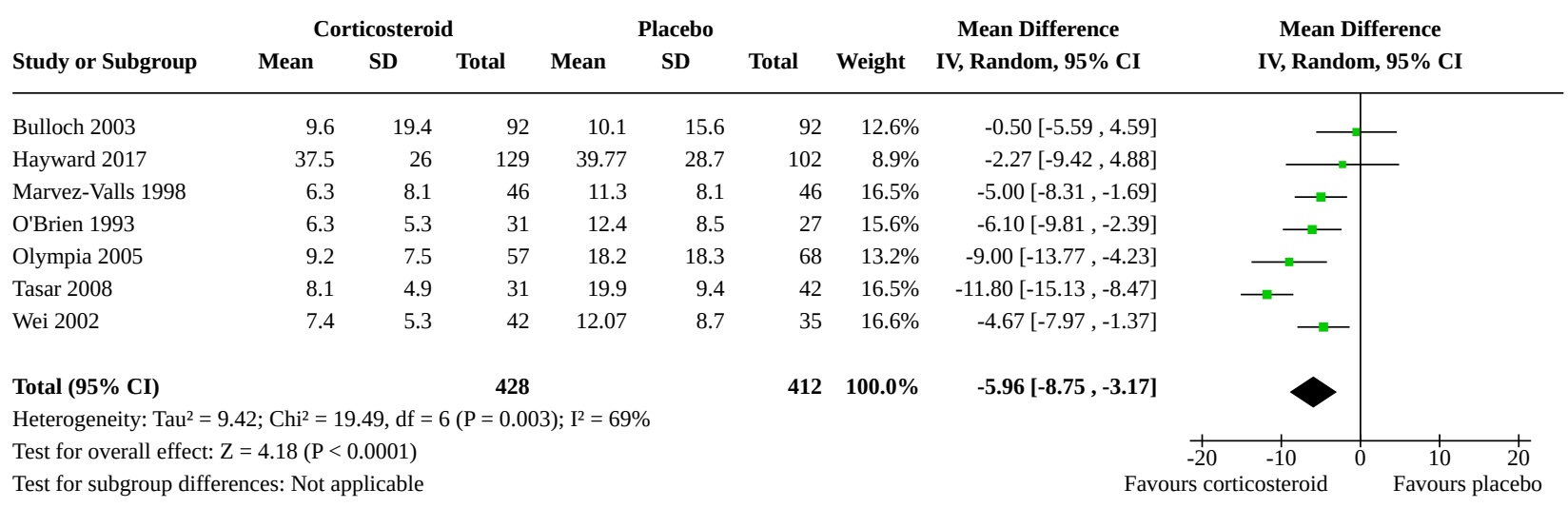

\section{Mean time to complete resolution of pain}

The mean time to complete resolution of pain was reduced by 11.6 hours in participants given corticosteroids (MD -11.6, 95\% $\mathrm{Cl}-22.17$ to $-1.08 ; \mathrm{P}=0.03 ; \mathrm{I}^{2}=81 \%$; Analysis 1.9 ). This analysis showed high heterogeneity, and sensitivity analysis (leave-one-out method) revealed a mean difference ranging from 8 to 15 hours ( $P$ $=0.02$ to $P<0.001$ ).

The trials by Bulloch 2003 and Hayward 2017 appeared to be the main contributors to heterogeneity in this analysis; removing these trials resulted in a mean time to complete pain resolution of 21 hours (MD $-21.01,95 \% \mathrm{Cl}-26.42$ to $-15.61 ; \mathrm{P}<0.001 ; \mathrm{I}^{2}$ $=9 \%$ ). Analysis of scores on the visual analogue scale for both studies suggested that participants may have experienced less severe sore throat symptoms initially. We assessed the evidence for this outcome as of moderate certainty.

\section{Secondary outcomes}

\section{Absolute reduction in pain measured by visual analogue scales}

We performed a pooled analysis of the absolute reduction in pain visual analogue scale (VAS) score for the seven studies reporting this outcome (Analysis 1.10) (Bulloch 2003; Hayward 2017; Kiderman 2005; Marvez-Valls 1998; O'Brien 1993; Olympia 2005; Wei 2002). The results indicated that participants who received corticosteroids and completed this scale experienced a $1.06 \mathrm{~cm}$ or $10.6 \%$ greater reduction in VAS score at 24 hours than those in the placebo group (MD 1.06, 95\% Cl 0.21 to 1.92). However, this result had high heterogeneity $\left(I^{2}=82 \%\right)$. One reason for this may be that the included trials used different versions of the VAS. Four studies used a 10-centimetre (0-to-10-point) VAS (Hayward 2017; Kiderman 2005; Marvez-Valls 1998; Wei 2002). One study used a McGrath Facial Affective scale, which was scored between 1 to 0 and included nine faces (Olympia 2005); one study used a 15-centimetre VAS with a score between 0 and 3.0 (O'Brien 1993); and one study used a colour analogue scale equivalent to a 10-centimetre VAS (Bulloch 2003). The trials by Bulloch 2003 and Hayward 2017 were again the main contributors to the high heterogeneity. We assessed the evidence for this outcome as of moderate certainty.

\section{Adverse events}

Two trials involving a total of 690 participants reported this outcome (Hayward 2017; Olympia 2005). Olympia 2005 reported that 5 participants $(4 \% ; 3$ corticosteroid and 2 placebo group participants) were hospitalised for fluid rehydration, and 3 participants (2\%; 1 corticosteroid and 2 placebo group participants) developed peritonsillar abscess. Hayward 2017 reported five serious adverse events: two events occurred in the corticosteroid group $(0.3 \%)$, one of which was considered to be related to the trial (hospital admission with parapharyngeal abscess), and three events $(1.1 \%)$ occurred in the placebo group (hospital admission with peritonsillar abscess, hospital admission with severe tonsillitis, and hospital admission with pneumonia, with subsequent death) (Analysis 1.11). Three trials reported either no side effects attributable to dexamethasone (O'Brien 1993); no complications of GABHS identified in either group (Bulloch 2003); or no participants with additional complaints or requiring additional medications (Tasar 2008). We assessed the evidence for this outcome as of moderate certainty.

\section{Recurrence/relapse rates}

Three trials reported rates of recurrence/relapse (Bulloch 2003; Kiderman 2005; Niland 2006). Pooled analysis showed a nonsignificant trend towards a lower risk of recurrence/relapse in the corticosteroid group in a very small number of cases (RR $0.52,95 \% \mathrm{Cl} 0.16$ to $1.73 ; \mathrm{P}=0.29 ; \mathrm{I}^{2}=23 \%$; Analysis 1.12 ). The rates of attendance for further care within five days reported in a single trial involving 118 participants were $0 / 39$ for intramuscular dexamethasone, $3 / 42$ for oral dexamethasone, and $6 / 37$ for placebo $(P=0.023)$ (Wei 2002). Hayward 2017 reported the rates of reconsultation at a healthcare facility within 28 days defined as attendance or telephone contact at any healthcare facility with symptoms or complications associated with sore throat, finding no significant difference in the number of participants re-consulting in either group. We assessed the evidence for this outcome as of moderate certainty.

\section{Days missed from school or work}

Only two trials provided data for this outcome (Hayward 2017; Marvez-Valls 1998). A pooled analysis showed no significant difference in days missed from work or school between groups (MD $-0.28,95 \% \mathrm{Cl}-0.84$ to $0.28 ; \mathrm{P}=0.33 ; \mathrm{I}^{2}=0 \%$; Analysis 1.13 ). Kiderman 2005 recorded no significant differences in time taken 
off work or studies between groups at any follow-up period but provided no supporting data. Niland 2006 reported no difference in the number of days missed from work or school with a significance value of $P=0.68$, but did not provide any further data. We assessed the evidence for this outcome as of moderate certainty.

\section{DISCUSSION}

\section{Summary of main results}

In participants with sore throat, oral or intramuscular corticosteroids in addition to antibiotics significantly increased the proportion of participants experiencing complete resolution of pain at 24 and 48 hours, although the effect was moderate. Five people need to be treated with corticosteroids to prevent one person continuing to experience pain at 24 hours. Corticosteroids decreased the mean time to onset of pain relief by 6 hours and the mean time to complete resolution of symptoms by 11.6 hours. However, both analyses were associated with high heterogeneity. Corticosteroids reduced the subjective rating of pain at 24 hours by an additional $10.6 \%$, again associated with high heterogeneity. Subgroup analyses revealed a greater effect size for intramuscular versus oral corticosteroids in both the proportion of participants achieving complete pain resolution at 24 hours and the mean time to onset of pain relief, although tests for subgroup effects did not reach significance. The effect on mean time to onset of pain relief was greater in those participants with severe, exudative, and bacterial pathogen-positive sore throat. A small number of trials reported adverse events, recurrence/relapse rates, or days missed from work or school; we found no difference in the likelihood of these outcomes between participants receiving corticosteroids and those receiving placebo. Only two trials reported funding sources.

\section{Overall completeness and applicability of evidence}

We included nine trials that were conducted in general practice and emergency department settings. Most trials were performed in the USA, and only two in Europe. Additional trial data may therefore be warranted in other populations, including those from lower- and middle-income countries, who are likely to differ in consultation patterns and clinical practice (including antibiotic prescribing guidelines), before the results can be generalised to other populations.

Only two trials included children, and the results of these trials were inconsistent, therefore we were unable to draw reliable conclusions about the clinical benefit of corticosteroids in this population. Children commonly present with sore throat, and it will be important to await results from future trials in these cohorts to develop a clearer understanding of whether corticosteroids also provide a benefit in this population.

The most important limitation to applicability of the evidence was that in eight of the nine included trials, participants received antibiotics in addition to corticosteroid or placebo treatment. Only one trial did not give immediate antibiotics, excluding those with a sore throat severe enough to require urgent antibiotics from the study, and asking clinicians to offer delayed antibiotics where they felt it to be necessary.

\section{Quality of the evidence}

Whilst we included only randomised, double-blind, placebocontrolled trials, in a number of cases the trials did not specify their methods of randomisation or allocation concealment. The included trials reported a variety of outcome measures, in some cases with inadequate reporting, no standard deviations, or use of graphical representation only. Significant heterogeneity was evident in a number of our analyses. This heterogeneity, and the relatively small number of participants in some analyses, resulted in a GRADE evidence certainty assessment of moderate for most of our analyses; the evidence for two analyses (complete resolution of pain at 24 hours and complete resolution of pain at 48 hours) was assessed as of high certainty.

The outcome measures of mean time to onset of pain relief and to complete resolution of pain were limited by recall bias because they relied on participants' subjective recall and recording. The mean time could also be skewed by a few participants who had sore throat pain for especially long or short periods. A median time may have been more appropriate, although data were insufficient to calculate this. The included studies were also underpowered to detect rare adverse effects of corticosteroid therapy, as well as relapse rates. Only two studies included missed days from work or school, making it difficult to draw robust conclusions from this analysis.

Finally, the limited number of trials meant that we were unable to assess publication bias using a funnel plot, although we attempted to address this issue by using citation searching.

\section{Potential biases in the review process}

We included one new study for this update (Hayward 2017). Hayward 2017 included authors involved in this Cochrane Review. To limit bias, Hayward 2017 was appraised and data extracted by two review authors who were not authors of the study. This review update was drafted by an author who was not a published author for Hayward 2017. As outlined in the Differences between protocol and review section, the primary outcomes were changed to reflect the available evidence and to focus on the most relevant symptom of sore throat (pain). Future updates will focus on these outcomes, but if other outcomes are routinely reported in future studies, such as painful swallowing, these could be included.

\section{Agreements and disagreements with other studies or reviews}

Four systematic reviews addressing the question of corticosteroids in sore throat have been published in addition to this Cochrane Review (Korb 2010; Mullarkey 2011; Sadeghirad 2017; Wing 2010).

This review update included a recent double-blind, placebocontrolled randomised trial by Hayward 2017. Inclusion of this trial greatly increased the numbers of participants incorporated into the analysis. Inclusion of the study reduced the effect size of likelihood of complete resolution of pain at 24 hours, with the effect size maintained at 48 hours. Similarly, the effect size of mean time to onset of pain relief was reduced, whilst mean time to complete resolution of pain was maintained. This is potentially explained by the exclusion criteria in Hayward 2017. Hayward 2017 sought to examine the effects of corticosteroids in the absence of antibiotics, and participants were not routinely given antibiotics. Those participants deemed to require immediate antibiotics at baseline were excluded from the study, which will have excluded those with the most severe sore throats. Although there was no significant difference in outcomes between those participants 
offered delayed antibiotic prescriptions and those who were not, it is possible that participants with more severe sore throats may derive a greater benefit from steroids early on in an infection, which was not captured in this review. The majority of participants included in this review were adults, whereas studies carried out in children have shown a significant benefit with corticosteroids (Bulloch 2003; Olympia 2005). Also, patients in the Hayward 2017 study were recruited from a general practitioner setting and not an emergency department setting, which could also account for a difference in baseline severity of symptoms. Finally, reporting of time to relief/resolution of pain differed across the studies, with Hayward 2017 contacting participants directly at 24 and 48 hours in addition to participants using a self-reported symptoms diary.

The most recent systematic review, Sadeghirad 2017, used a similar search strategy to this update and included all trials included in our review as well as a trial by Ahn 2003. We had previously identified this trial as providing poor-certainty evidence, requiring estimation of standard deviations and scoring zero on the Jadad scale (Jadad 1996). Personal communication with the trial authors revealed that this was not a double-blind randomised controlled trial. No placebo was given, and participants were not randomised but rather treated consecutively until equal numbers were achieved in both treatment groups. Consequently, we excluded Ahn 2003 from our review. Although Sadeghirad 2017 identified this bias, the study was included in the analysis, therefore likely accounting for the shorter mean time to onset of pain relief found in participants treated with corticosteroids of 4.8 hours $(95 \% \mathrm{Cl}-1.9$ to -7.8$)$. Overall, participants taking corticosteroids were twice as likely as placebo participants to experience pain relief at 24 hours (RR 2.2, $95 \% \mathrm{Cl} 1.2$ to 4.3 ) and 1.5 times as likely to experience pain resolution at 48 hours ( $\mathrm{RR} 1.5,95 \% \mathrm{Cl} 1.3$ to 1.8 ). These results were in line with our findings.

Korb 2010 used a similar search strategy to our review but did not search the Database of Abstracts of Reviews of Effects (DARE), the NHS Economic Evaluation Database (NHS EED), or the World Health Organization (WHO) International Clinical Trials Registry Platform (ICTRP). Korb 2010 included all trials included in our review with the exception of Hayward 2017, but did not document excluded trials. Although Korb 2010 did not perform a meta-analysis, similar conclusions to our review were drawn regarding a small but significant beneficial effect of corticosteroids using a descriptive analysis.

Wing 2010 performed an extensive search of the literature, including conference proceedings. In addition to eight of the nine trials included in our review (the exception was Hayward 2017), Wing 2010 also included two trials with low-certainty evidence (Ahn 2003; Hahn 1951). Hahn 1951 achieved a Jadad score of zero and did not contribute any data to the meta-analyses. We excluded Hahn 1951 from our review because it was performed in hospitalised participants. However, results reported by Wing 2010, including the trials with low-certainty evidence, are also in line with our review. Wing 2010 reported mean time to clinically meaningful pain relief as 4.5 hours (MD $-4.54,95 \% \mathrm{Cl}-7.19$ to $-1.89 ; \mathrm{I}^{2}=81 \%$; $\mathrm{P}<0.001$ ), compared to 6 hours in our review, but failed to address the high heterogeneity in this analysis. Wing 2010 also presented a metaanalysis of absolute VAS scores at 24 hours and demonstrated an MD of -0.9 on a 0 -to- 10 VAS (MD $-0.9,95 \% \mathrm{Cl}-1.5$ to $-0.3 ;\left.\right|^{2}=74 \%$, $P=0.003)$. This is a difficult finding to interpret because it did not take account of the baseline VAS score, which was variable amongst studies. The trial authors argued that a reduction of 1.3 points represents a clinically meaningful change, and hence this was not a significant result. However, this a priori level of significance has not been extensively validated in the field. In our analysis, which accounted for baseline scores by assessing change from baseline, we found that the reduction from baseline was greater in the corticosteroid group by $11 \%$, or $1.1 \mathrm{~cm}$.

Mullarkey 2011 was a single-author systematic review that limited the search to adult participants presenting to emergency departments. Mullarkey 2011 included five of the studies included in our review and one systematic review (Hayward 2009), but no additional studies. No meta-analysis was attempted. A descriptive analysis was supportive of the benefit of corticosteroids as an adjunct in the management of acute pharyngitis.

\section{AUTHORS' CONCLUSIONS}

\section{Implications for practice}

Our findings suggest that in participants with sore throat, pain can be reduced and resolution hastened by use of a single dose of oral or intramuscular corticosteroids in conjunction with antibiotic therapy.

Our finding of a reduction in the duration of pain by six hours seems modest. However, the decision to use any treatment involves balancing the potential benefits and harms of the therapy. The studies included in this review did not demonstrate increased side effects in participants receiving corticosteroids, but these studies were unlikely to be powered sufficiently to detect adverse effects of short courses of oral corticosteroids, and reporting of adverse events was poor. A previous review suggested that courses shorter than one week were unlikely to be harmful (Richards 2008). A recent self-controlled case series of adults in the USA showed higher rates of sepsis, venous thromboembolism, and fractures within a 30-day hospitalisation follow-up period following one short course of oral steroids (Waljee 2017). However, concerns have been raised regarding confounding by indication in this study and the mechanisms driving these outcomes. It may also be possible that short-courses of corticosteroids for sore throat could lead to 'medicalisation' of this condition, resulting in larger cumulative doses of corticosteroids being taken by patients overall. This has been seen regarding the use of antibiotics in sore throat (Little 1997). Finally, only one large study looked at the effects of corticosteroids on sore throat without antibiotics, and the effect found was modest (Hayward 2017). Given this conflicting evidence, and the potential impact of medicalisation on corticosteroid use, further research into the harms and benefits of short courses and multiple short courses of corticosteroids are needed to permit informed decision making, especially when the benefit is limited. This is particularly the case for patients who have comorbidities, as the participants included in these studies were largely healthy based on stated exclusion criteria.

Ideally, steroids would not only improve symptoms but also reduce the need for antibiotics for sore throat. Only three trials presented any data on outcomes in the absence of immediate antibiotics. Two trials including only children evaluating a single dose of oral dexamethasone reported on a subgroup of children (total 154) where rapid streptococcal antigen testing was negative, and antibiotics were only offered if a throat swab culture was positive, although antibiotic use from other healthcare sources 
was not documented (Bulloch 2003; Olympia 2005). These trials had opposing findings: Olympia 2005 used a minimum subjective pain score as an inclusion criterion and found that dexamethasone reduced duration of sore throat, increased change in pain score, and hastened onset of pain relief, whilst Bulloch 2003 found no benefit of dexamethasone on time to clinically significant pain relief or time to complete pain relief. In Bulloch 2003, 24\% of children reported mild pain at inclusion. Further research in children is needed before recommendations about practice can be made in this population. In adults with sore throat not deemed to require immediate antibiotics, a single dose of dexamethasone resulted in an increased likelihood of complete resolution of symptoms at 48 hours but conferred no benefit in terms of duration of symptoms or pain scores (Hayward 2017). It is possible that the severity of the included population could explain the differential effects seen in these trials.

We could not fully assess the optimal formulation, route of administration, or dosing regimen of corticosteroids due to small sample sizes. Two studies that directly compared intramuscular and oral administration routes found no differences (Marvez-Valls 2002; Wei 2002), and no significant differences were seen in our subgroup analyses. Because oral corticosteroids may be more acceptable to patients, and appear to be equally beneficial as intramuscular preparations, we would suggest use of the oral route of administration. In terms of dosing regimen, only two trials compared single and multiple doses of dexamethasone. Kiderman 2005 reported a significant benefit of two days compared to one day of treatment but failed to provide any supporting data. Niland 2006 found no difference in outcomes between one- and three-day courses of treatment.

\section{Implications for research}

There is still a need for trials of corticosteroids for sore throat for children and adolescents in primary care settings. In addition, trials are needed across all age groups that compare analgesia to corticosteroids in the absence of antibiotics. Currently, there are limited data in children. Only two trials evaluating children were identified in this review, therefore it is difficult to draw conclusions about practice in this cohort. There appears to be sufficient evidence that oral corticosteroids are as effective in adults as intravenous corticosteroids, therefore it seems there is little reason to further compare oral versus intravenous routes of administration. Using widely recognised severity criteria such as the Centor criteria, Fine 2012, or FeverPAIN score, Little 2013, at baseline may facilitate more accurate classification of severity of sore throat and investigation as to whether steroids can avoid immediate antibiotics in those patients with more severe sore throats who are more likely to seek treatment. Outcomes assessed should include the number of participants who experience resolution of symptoms at 24,48 , and 72 hours, measured using standardised pain scores. Additional outcomes should include effects of corticosteroids on antibiotic use, days missed from school/college or work, as well as longer-term measures such as reattendance with sore throat. Trials should be sufficiently powered to assess adverse outcomes, particularly in participants with other comorbidities, as well as effects on complications, secondary care admissions, and associated costs.

\section{ACKNOWLEDGEMENTS}

The review authors wish to thank the following people for commenting on the draft protocol: Anne Lyddiatt, Jeffrey Linder, Nelcy Rodriguez, and Taixiang $\mathrm{Wu}$, and for commenting on the original draft review: Noorin Bhimani, Ankur Barua, Blake Bulloch, Caitriona Mullarkey, Max Bulsara, and Taixiang Wu. We thank the following people for commenting on this updated review: Ann Fonfa, Anne Lyddiatt, Craig Mellis, Conor Teljeur, and Roderick Venekamp. 


\section{R E F E R E N C E S}

\section{References to studies included in this review}

Bulloch 2003 \{published data only\}

Bulloch B, Kabani A, Tenenbein M. Oral dexamethasone for the treatment of pain in children with acute pharyngitis: a randomized, double-blind, placebo-controlled trial. Annals of Emergency Medicine 2003;41(5):601-8.

\section{Hayward 2017 \{published data only\}}

Hayward GN, Hay AD, Moore MV, Jawad S, Williams N, Voysey M, et al. Effect of oral dexamethasone without immediate antibiotics vs placebo on acute sore throat in adults: a randomised clinical trial. JAMA 2017;317(15):1535-43.

\section{Kiderman 2005 \{published data only\}}

Kiderman A, Yaphe J, Bregman J, Zemel T, Furst AL. Adjuvant prednisone therapy in pharyngitis: a randomised controlled trial from general practice. British Journal of General Practice 2005;55(512):218-21.

\section{Marvez-Valls 1998 \{published data only\}}

Marvez-Valls EG, Ernst AA, Gray J, Johnson WD. The role of betamethasone in the treatment of acute exudative pharyngitis. Academic Emergency Medicine 1998;5(6):567-72.

\section{Niland 2006 \{published data only\}}

Niland ML, Bonsu BK, Nuss KE, Goodman DG. A pilot study of 1 versus 3 days of dexamethasone as add-on therapy in children with streptococcal pharyngitis. Pediatric Infectious Disease Journal 2006;25(6):477-81.

\section{O'Brien 1993 \{published data only\}}

O'Brien JF, Meade JL, Falk JL. Dexamethasone as adjuvant therapy for severe acute pharyngitis. Annals of Emergency Medicine 1993;22(2):212-5.

\section{Olympia 2005 \{published data only\}}

* Olympia RP, Khine H, Avner JR. Effectiveness of oral dexamethasone in the treatment of moderate to severe pharyngitis in children. Archives of Pediatrics \& Adolescent Medicine 2005;159(3):278-82.

Olympia RP, Khine H, Avner JR. The effectiveness of oral dexamethasone in the treatment of moderate to severe pharyngitis in children and young adults. Academic Emergency Medicine 2003;10(5):434-a.

\section{Tasar 2008 \{published data only\}}

Tasar A, Yanturali S, Topacoglu H, Ersoy G, Unverir P, Sarikaya S. Clinical efficacy of dexamethasone for acute exudative pharyngitis. Journal of Emergency Medicine 2008;35(4):363-7.

\section{Wei 2002 \{published data only\}}

Wei JL, Kasperbauer JL, Weaver AL, Boggust AJ. Efficacy of single-dose dexamethasone as adjuvant therapy for acute pharyngitis. Laryngoscope 2002;112(1):87-93.

\section{References to studies excluded from this review}

Ahn 2003 \{published data only\}

Ahn JH, Woo WK, Kim YS, Song YJ, Jeon IK, Jung JR, et al. Efficacy of adjuvant short term oral therapy for acute pharyngitis. Korean Journal of Otolaryngology 2003;46(11):971-4.

\section{Armstrong 2018 \{published data only\}}

Armstrong C. Corticosteroids for sore throat: BMJ Rapid Recommendation. American Family Physician 2018;15:821.

Chen 2018 \{published data only\}

Chen QP, Zhou RF, Zhang YM, Yang L. Efficacy of systemic glucocorticoids combined with inhaled steroid on children with acute laryngitis. Chinese Journal of Otorhinolaryngology Head and Neck Surgery 2018;53(1):53-6.

Chenot 2018 \{published data only\}

Chenot JF, Angelow A, Weckmann G. Dexamethasone and other corticosteroids for acute pharyngitis. Internistische Praxis 2018:59:327-35.

Hahn 1951 \{published data only\} Hahn EO, Houser HB, Rammelkamp CH Jr, Denny FW, Wannamaker LW. Effect of cortisone on acute streptococcal infections and poststreptococcal complications. Journal of Clinical Investigation 1951;30(3):274-81. [PMID: 14824277]

Hristea 2013 \{published data only\} Hristea A, Jipa R, Streinu-Cercel O. Do we know the place of systemic corticosteroids in infectious diseases? BMC Infectious Diseases 2013;13:023.

Marvez-Valls 2002 \{published data only\}

Marvez-Valls EG, Stuckey A, Ernst AA. A randomized clinical trial of oral versus intramuscular delivery of steroids in acute exudative pharyngitis. Academic Emergency Medicine 2002;9(1):9-14

Shaughnessy 2018 \{published data only\}

Shaughnessy AF. Single-dose oral dexamethasone decreases sore throat pain. American Family Physician 2018;97:4.

Welch 2014 \{published data only\}

Welch JL, Cooper DD. Do corticosteroids benefit patients with sore throat? Annals of Emergency Medicine 2014;63:711-2.

\section{References to ongoing studies}

ACTRN12618000017224 \{published data only\}

ACTRN12618000017224. Use of oral prednisone in acute sore throats [Use of oral prednisone in the treatment of acute sore throat - a randomised control trial]. www.anzctr.org.au/Trial/ Registration/TrialReview.aspx?id=373867 (first received 11 January 2018) 
ACTRN12618000847213 \{published data only\}

ACTRN12618000847213. Efficacy of single dose dexamethasone in the management of sore throat [Efficacy of single dose dexamethasone in the management of sore throat in primary care setting - randomized controlled trial]. www.anzctr.org.au/ Trial/Registration/TrialReview.aspx?ACTRN=12618000847213 (first received 24 June 2018).

\section{Additional references}

\section{Atkins 2004}

Atkins D, Best D, Briss PA, Eccles M, Falck-Ytter Y, Flottorp S, et al, GRADE Working Group. Grading quality of evidence and strength of recommendations. BMJ 2004;328(7454):1490.

\section{Bisno 2001}

Bisno AL. Acute pharyngitis. New England Journal of Medicine 2001;344(3):205-11.

\section{Costelloe 2010}

Costelloe C, Metcalfe C, Lovering A, Mant D, Hay A. Effect of antibiotic prescribing in primary care on antimicrobial resistance in individual patients: systematic review and metaanalysis. BMJ 2010;340:2096.

\section{Fine 2012}

Fine AM, Nizet V, Mandl KD. Large-scale validation of the Centor and Mclsaac scores to predict Group A streptococcal pharyngitis. Archives of Internal Medicine 2012;172(11):847-52.

\section{Gates 2018}

Gates A, Gates M, Vandermeer B, Johnson C, Hartling L, Johnson DW, et al. Glucocorticoids for croup in children. Cochrane Database of Systematic Reviews 2018, Issue 8. [DOI: 10.1002/14651858.CD001955.pub4]

\section{Grab It! XP 2010 [Computer program]}

Microsoft Office Grab It! XP Microsoft Excel. Redmond: Microsoft Office, 2010.

\section{GRADEpro GDT 2015 [Computer program]}

McMaster University (developed by Evidence Prime) GRADEpro GDT. Version accessed May 2019. Hamilton (ON): McMaster University (developed by Evidence Prime), 2015.Available at gradepro.org.

\section{Gulliford 2009}

Gulliford M, Latinovic R, Charlton J, Little P, van Staa T, Ashworth M. Selective decrease in consultations and antibiotic prescribing for acute respiratory tract infections in UK primary care up to 2006. Journal of Public Health (Oxford, England) 2009;31(4):512-20.

\section{Gulliford 2014}

Gulliford M, Dregan A, Moore MV, Ashworth M, van Staa T, McCann $\mathrm{G}$, et al. Continued high rates of antibiotic prescribing to adults with respiratory tract infection: survey of $568 \mathrm{UK}$ general practices. BMJ Open 2014;4(10):e006245. [DOI: 10.1136/ bmjopen-2014-006245]

\section{Harris 2016}

Harris AM, Hicks LA, Qaseem A, High Value Care Task Force of the American College of Physicians and for the Centers for Disease Control and Prevention. Appropriate antibiotic use for acute respiratory tract infection in adults: advice for high-value care from the American College of Physicians and the Centers for Disease Control and Prevention. Annals of Internal Medicine 2016;164(6):425-34.

\section{Hayward 2009}

Hayward G, Thompson M, Heneghan C, Perera R, Del Mar C, Glasziou P. Corticosteroids for pain relief in sore throat: systematic review and meta-analysis. BMJ 2009;339:b2976. [PMID: 19661138]

\section{Higgins 2003}

Higgins JP, Thompson SG, Deeks JJ, Altman DG. Measuring inconsistency in meta-analyses. BMJ 2003;327(7414):557-60.

\section{Higgins 2011}

Higgins JP, Green S, editor(s). Cochrane Handbook for Systematic Reviews of Interventions. Version 5.1.0 (updated March 2011). The Cochrane Collaboration, 2011. Available from handbook.cochrane.org.

\section{Howie 1985}

Howie JG, Foggo BA. Antibiotics, sore throats and rheumatic fever. Journal of the Royal College of General Practitioners 1985;35(274):223-4.

\section{Jadad 1996}

Jadad AR, Moore RA, Carroll D, Jenkinson C, Reynolds DJ, Gavaghan DJ, et al. Assessing the quality of reports of randomized clinical trials: is blinding necessary? Controlled Clinical Trials 1996;17(1):1-12. [PMID: 8721797]

\section{Korb 2010}

Korb K, Scherer M, Chenot JF. Steroids as adjuvant therapy for acute pharyngitis in ambulatory patients: a systematic review. Annals of Family Medicine 2010;8(1):58-63.

\section{Lefebvre 2011}

Lefebvre C, Manheimer E, Glanville J. Chapter 6: Searching for studies. In: Higgins JP, Churchill R, Chandler J, Cumpston MS, editor(s). Cochrane Handbook for Systematic Reviews of Interventions. Version 5.2.0 (updated June 2017). The Cochrane Collaboration, 2017. Available from www.training.cochrane.org/ handbook.

\section{Linder 2005}

Linder JA, Bates DW, Lee GM, Finkelstein JA. Antibiotic treatment of children with sore throat. JAMA 2005;294(18):2315-22.

\section{Little 1997}

Little P, Williamson I, Warner G, Gould C, Gantley M, Kinmonth AL. Open randomised trial of prescribing strategies in managing sore throat. BMJ 1997;314(7082):722-7. 


\section{Little 2002}

Little P, Watson L, Morgan S, Williamson I. Antibiotic prescribing and admissions with major suppurative complications of respiratory tract infections: a data linkage study. British Journal of General Practice 2002;52(476):187-90, 193.

\section{Little 2013}

Little P, Moore M, Hobbs FD, Mant D, McNulty C, Williamson I, et al, PRISM investigators. PRImary care Streptococcal Management (PRISM) study: identifying clinical variables associated with Lancefield group A $\beta$-haemolytic streptococci and Lancefield non-Group A streptococcal throat infections from two cohorts of patients presenting with an acute sore throat. BMJ Open 2013;3(10):e003943. [DOI: 10.1136/ bmjopen-2013-003943]

\section{Moher 2009}

Moher D, Liberati A, Tetzlaff J, Altman DG, The PRISMA Group. Preferred reporting items for systematic reviews and metaanalyses: The PRISMA Statement. BMJ 2009;339:2535.

\section{Mullarkey 2011}

Mullarkey C. Soothing a sore throat: the efficacy and safety of steroids in acute pharyngitis. Irish Journal of Medical Science 2011;180(4):837-40.

\section{Mygind 2001}

Mygind N, Nielsen LP, Hoffmann HJ, Shukla A, Blumberga G, Dahl R, et al. Mode of action of intranasal corticosteroids. Journal of Allergy and Clinical Immunology 2001;108(Suppl 1):16-25.

\section{NICE 2008}

National Institute for Health and Care Excellence. Respiratory tract infections (self-limiting): prescribing antibiotics. www.nice.org.uk/guidance/cg69 (accessed prior to 29 July 2019).

\section{NICE 2018}

National Institute for Health and Care Excellence. Sore throat (acute): antimicrobial prescribing. www.nice.org.uk/guidance/ ng84 (accessed prior to 27 July 2019).

\section{Petersen 2007}

Petersen I, Johnson AM, Islam A, Duckworth G, Livermore DM, Hayward AC. Protective effect of antibiotics against serious complications of common respiratory tract infections: retrospective cohort study with the UK General Practice Research Database. BMJ 2007;335(7627):982.

\section{Review Manager 2014 [Computer program]}

Nordic Cochrane Centre, The Cochrane Collaboration Review Manager 5 (RevMan 5). Version 5.3. Copenhagen: Nordic Cochrane Centre, The Cochrane Collaboration, 2014.

\section{Rezk 2015}

Rezk E, Nofal YH, Hamzeh A, Aboujaib MF, AlKheder MA, Al Hammad MF. Steroids for symptom control in infectious mononucleosis. Cochrane Database of Systematic Reviews 2015, Issue 11. [DOI: 10.1002/14651858.CD004402.pub3]

\section{Richards 2008}

Richards RN. Side effects of short-term oral corticosteroids. Journal of Cutaneous Medicine and Surgery 2008;12(2):77-81. [PMID: 18346404]

\section{Sadeghirad 2017}

Sadeghirad B, Siemieniuk RAC, Brignardello-Petersen R, Papola D, Lytvyn L, Vandvik P, et al. Corticosteroids for treatment of sore throat: systematic review and meta-analysis of randomised trials. BMJ 2017;358:3887.

\section{Schappert 2008}

Schappert SM, Rechtsteiner EA. Ambulatory medical care utilization estimates for 2006. National Health Statistics Reports 2008;6(8):1-29.

\section{Sharland 2005}

Sharland M, Kendall H, Yeates D, Randall A, Hughes G, Glasziou P, et al. Antibiotic prescribing in general practice and hospital admissions for peritonsillar abscess, mastoiditis, and rheumatic fever in children: time trend analysis. BMJ 2005;331(7512):328-9.

\section{SMAC 1998}

Standing Medical Advisory Committee, SubGroup on Antimicrobial Resistance, Department of Health. The path of least resistance. webarchive.nationalarchives.gov.uk/20081106020107/http:// www.dh.gov.uk/en/Publicationsandstatistics/Publications/ PublicationsPolicyAndGuidance/DH_4009357 (accessed prior to 29 July 2019).

\section{Spinks 2013}

Spinks A, Glasziou PP, Del Mar CB. Antibiotics for sore throat. Cochrane Database of Systematic Reviews 2013, Issue 11. [DOI: 10.1002/14651858.CD000023.pub4]

\section{Stovold 2014}

Stovold E, Beecher D, Foxlee R, Noel-Storr A. Study flow diagrams in Cochrane systematic review updates: an adapted PRISMA flow diagram. Systematic Reviews 2014;3:54.

\section{Waljee 2017}

Waljee AK, Rogers MA, Lin P, Singal AG, Stein JD, Marks RM, et al. Short term use of oral corticosteroids and related harms among adults in the United States: population based cohort study. BMJ 2017;357:1415.

\section{Wing 2010}

Wing A, Villa-Roel C, Yeh B, Eskin B, Buckingham J, Rowe BH. Effectiveness of corticosteroid treatment in acute pharyngitis: a systematic review of the literature. Academic Emergency Medicine 2010;17(5):476-83.

\section{Zalmanovici Trestioreanu 2013}

Zalmanovici Trestioreanu A, Yaphe J. Intranasal steroids for acute sinusitis. Cochrane Database of Systematic Reviews 2013, Issue 12. [DOI: 10.1002/14651858.CD005149.pub4] 


\section{References to other published versions of this review}

\section{Hayward 2012}

Hayward G, Thompson MJ, Perera R, Glasziou PP, Del Mar CB, Heneghan CJ. Corticosteroids as standalone or add-on treatment for sore throat. Cochrane Database of Systematic Reviews 2012, Issue 5. [DOI: 10.1002/14651858.CD008268.pub2]

\section{CHARACTERISTICS OF STUDIES}

Characteristics of included studies [ordered by study ID]

Bulloch 2003

\section{Study characteristics}

\begin{tabular}{ll}
\hline Methods & $\begin{array}{l}\text { Randomised, double-blind, placebo-controlled trial in an emergency department setting in Canada. 1- } \\
\text { month follow-up }\end{array}$ \\
\hline Participants & $\begin{array}{l}184 \text { children (92 in each group) aged } 5 \text { to } 16 \text { years (mean } 9.74 \text { years) presenting with erythema of } \\
\text { the pharyn, onset of symptoms within the previous } 48 \text { hours, and } 1 \text { chief complaint of sore throat, } \\
\text { odynophagia, or dysphagia }\end{array}$
\end{tabular}

Interventions

Dexamethasone $0.6 \mathrm{mg} / \mathrm{kg}$ orally (maximum of $10 \mathrm{mg}$ ) or placebo orally. All participants with a positive direct antigen test for Streptococcus pyogenes group A antigen from pharyngeal swabs were treated with penicillin $\mathrm{V}$.

\section{Thompson 2010}

Thompson MJ, Hayward G, Heneghan CJ, Perera R, Glasziou PP, Del Mar CB. Corticosteroids for sore throat. Cochrane Database of Systematic Reviews 2010, Issue 1. [DOI: 10.1002/14651858.CD008268]

* Indicates the major publication for the study Reduction in pain VAS. Time to onset of pain relief, time to complete pain resolution, percentage recurrence

$\begin{array}{ll}\text { Notes } & \begin{array}{l}\text { Analgesia unregulated and unrecorded. Funding source: supported by the Dr Paul HT Thorlakson Foun- } \\ \text { dation Fund. No conflict of interest declared. No contact with study authors. }\end{array}\end{array}$

\section{Risk of bias}

\begin{tabular}{lll}
\hline Bias & Authors' judgement & Support for judgement \\
\hline $\begin{array}{l}\text { Random sequence genera- } \\
\text { tion (selection bias) }\end{array}$ & Low risk & $\begin{array}{l}\text { Block randomisation table with groups of } 10 \text { held at a central pharmacy. } 2 \text { lists } \\
\text { used for those positive and negative on direct antigen testing. Attempted to } \\
\text { enrol consecutive children but missed some eligible children when the emer- } \\
\text { gency department was too busy to permit enrolment. }\end{array}$ \\
\end{tabular}

\begin{tabular}{lll}
\hline $\begin{array}{l}\text { Allocation concealment } \\
\text { (selection bias) }\end{array}$ & Low risk & Placebo with identical appearance and taste used. \\
\hline $\begin{array}{l}\text { Blinding (performance } \\
\text { bias and detection bias) } \\
\text { All outcomes }\end{array}$ & Low risk & $\begin{array}{l}\text { Double-blind design. Randomisation code known only pharmacy and not bro- } \\
\text { ken until all participants recruited. Outcome assessors blinded to treatment } \\
\text { groups. }\end{array}$ \\
\hline $\begin{array}{l}\text { Incomplete outcome data } \\
\text { (attrition bias) } \\
\text { All outcomes }\end{array}$ & Low risk & $5 / 184$ failed to complete. \\
\hline
\end{tabular}

\begin{tabular}{lll}
\hline $\begin{array}{l}\text { Selective reporting (re- } \\
\text { porting bias) }\end{array}$ & Low risk & $\begin{array}{l}\text { Main outcome measures in similar trials included. No outcome measures as- } \\
\text { sessed were not reported. Data and confidence intervals clearly reported. }\end{array}$ \\
\hline $\begin{array}{l}\text { Comparability of groups at } \\
\text { baseline }\end{array}$ & Low risk & Comparable \\
\hline
\end{tabular}


Hayward 2017

\section{Study characteristics}

\begin{tabular}{ll}
\hline Methods & $\begin{array}{l}\text { Randomised, double-blind, placebo-controlled trial in general practice setting in the UK. 28-day fol- } \\
\text { low-up }\end{array}$ \\
\hline Participants & $\begin{array}{l}576 \text { adults aged over } 18 \text { years presenting to primary care with acute symptoms (onset < } 7 \text { days) of sore } \\
\text { throat and odynophagia deemed to be caused by an infection but not needing immediate antibiotics } \\
\text { were randomised. } 293 \text { randomised to dexamethasone group, } 283 \text { to placebo group. }\end{array}$ \\
\hline Interventions & Single dose 10 mg oral dexamethasone or oral placebo (lactulose). Clinician discretion to offer delayed \\
antibiotic prescription or no antibiotics. \\
\hline Outcomes
\end{tabular}

Notes

Declaration of interest: Drs Thompson and Heneghan have declared conflicts of interest as outlined in the primary study paper (DOI: 10.1001/jama.2017.3417). Funding source: work was supported by the National Institute for Health Research School for Primary Care Research (NIHRSPCR). Contact with study authors: no contact related to the study.

\section{Risk of bias}

Bias Authors' judgement Support for judgement

Random sequence genera- Low risk tion (selection bias)

Randomisation stratified (1:1) by study centre and receipt of a delayed antibiotic prescription. Computer-generated block randomisation (size 2, 4, or 6). Each site held 2 sets of packs of 2 to 3 blocks of blinded pre-randomised medication (for those who were offered antibiotic prescription and those who were not).

\begin{tabular}{ll}
\hline $\begin{array}{l}\text { Allocation concealment } \\
\text { (selection bias) }\end{array}$ & Low risk
\end{tabular}

\begin{tabular}{|c|c|c|}
\hline $\begin{array}{l}\text { Blinding (performance } \\
\text { bias and detection bias) } \\
\text { All outcomes }\end{array}$ & Low risk & $\begin{array}{l}\text { Participants and doctors (who were also outcome assessors) blinded to treat- } \\
\text { ment given. }\end{array}$ \\
\hline
\end{tabular}

\begin{tabular}{|c|c|c|}
\hline $\begin{array}{l}\text { Incomplete outcome data } \\
\text { (attrition bias) }\end{array}$ & Low risk & $\begin{array}{l}\text { Primary outcome: } 21 / 293 \text { lost to follow-up in dexamethasone group, } 14 / 283 \\
\text { lost to follow-up in placebo group }\end{array}$ \\
\hline
\end{tabular}

All outcomes

\begin{tabular}{lll}
\hline $\begin{array}{l}\text { Selective reporting (re- } \\
\text { porting bias) }\end{array}$ & Low risk & All outcomes reported. \\
\hline $\begin{array}{l}\text { Comparability of groups at } \\
\text { baseline }\end{array}$ & Low risk & Comparable \\
\hline
\end{tabular}


Kiderman 2005

\section{Study characteristics}

\begin{tabular}{ll}
\hline Methods & $\begin{array}{l}\text { Randomised, double-blind, placebo-controlled trial in general practice setting in Israel. 14-day fol- } \\
\text { low-up }\end{array}$ \\
\hline Participants & $\begin{array}{l}79 \text { participants aged } 18 \text { to } 65 \text { years (mean } 33.9 \text { years) complaining of severe sore throat and at least } 2 \\
\text { out of: tonsillar/pharyngeal exudate, dysphagia, fever, lymphadenopathy }\end{array}$ \\
\hline Interventions & $\begin{array}{l}\text { Prednisolone } 60 \mathrm{mg} \text { orally for either } 1 \text { or } 2 \text { days (40 participants) or placebo orally (39 participants). An- } \\
\text { tibiotics (penicillin V, amoxicillin, or erythromycin) prescribed at general practitioner's discretion. }\end{array}$ \\
\hline Outcomes & $\begin{array}{l}\text { Reduction in VAS score. Percentage of participants pain-free at various time points. Percentage recur- } \\
\text { rence. Complete resolution of pain at } 24 \text { and } 48 \text { hours. Days missed from school or work }\end{array}$ \\
\hline Notes & $\begin{array}{l}\text { Data from 1- and 2-day arms not presented separately. Analgesia unregulated and unrecorded. Decla- } \\
\text { ration of interest: none declared. No contact with study authors. Funding source: not declared }\end{array}$ \\
\hline
\end{tabular}

\section{Risk of bias}

\begin{tabular}{lll}
\hline Bias & Authors' judgement & Support for judgement \\
\hline $\begin{array}{l}\text { Random sequence genera- } \\
\text { tion (selection bias) }\end{array}$ & High risk & $\begin{array}{l}\text { Treatment packages prepared using a random number table generated using } \\
\text { an electronic spreadsheet. Chance selection of treatment package then used } \\
\text { to assign participants to groups. }\end{array}$ \\
\hline $\begin{array}{l}\text { Allocation concealment } \\
\text { (selection bias) }\end{array}$ & Low risk & Placebo drug identical to active tablets \\
\hline $\begin{array}{l}\text { Blinding (performance } \\
\text { bias and detection bias) }\end{array}$ & Low risk & $\begin{array}{l}\text { Participants and doctors (who were also outcome assessors) blinded to treat- } \\
\text { ment given. }\end{array}$ \\
\hline $\begin{array}{l}\text { Incomplete outcome data } \\
\text { (attrition bias) } \\
\text { All outcomes }\end{array}$ & Low risk & No participants lost to follow-up. \\
\hline $\begin{array}{l}\text { Selective reporting (re- } \\
\text { porting bias) }\end{array}$ & High risk & $\begin{array}{l}\text { No data reported for } 1 \text { dose versus 2 doses of prednisolone, despite text re- } \\
\text { porting of a significant dose effect. }\end{array}$ \\
\hline $\begin{array}{l}\text { Comparability of groups at } \\
\text { baseline }\end{array}$ & Low risk & Comparable \\
\hline
\end{tabular}

Marvez-Valls 1998

\section{Study characteristics}

Methods

Randomised, double-blind, placebo-controlled trial in an emergency department setting in the USA. Follow-up until resolution of pain; longest contact with participant for follow-up was 124 hours.

Participants

92 participants (46 in each group) aged 14 to 65 years (mean 29.1 years) presenting with symptoms of sore throat or odynophagia, dysphagia, fever, or cervical lymphadenopathy and appearances of exudative pharyngitis 
Marvez-Valls 1998 (Continued)

Interventions

Dexamethasone $2 \mathrm{~mL}$ IM ( $8 \mathrm{mg}$ is an approximate dosage based on USA formularies) or saline $2 \mathrm{~mL}$ IM. Antibiotics given to all participants. 1.2 million units benzathine penicillin IM or a 10-day course of erythromycin $500 \mathrm{mg}$ twice daily

\begin{tabular}{ll}
\hline Outcomes & $\begin{array}{l}\text { Reduction in pain VAS. Time to onset of pain relief. Time to complete pain resolution. Days missed from } \\
\text { school/work. Percentage recurrence }\end{array}$ \\
\hline Notes & $\begin{array}{l}\text { Analgesia unrecorded and unregulated. Funding source/declaration of interest: not declared. No con- } \\
\text { tact with study authors. }\end{array}$
\end{tabular}

\section{Risk of bias}

\begin{tabular}{|c|c|c|}
\hline Bias & Authors' judgement & Support for judgement \\
\hline $\begin{array}{l}\text { Random sequence genera- } \\
\text { tion (selection bias) }\end{array}$ & Low risk & Randomised list for assignment of participants \\
\hline $\begin{array}{l}\text { Allocation concealment } \\
\text { (selection bias) }\end{array}$ & Unclear risk & Not specifically commented upon \\
\hline $\begin{array}{l}\text { Blinding (performance } \\
\text { bias and detection bias) } \\
\text { All outcomes }\end{array}$ & Low risk & $\begin{array}{l}\text { Physician and participant blinded to the study drug used. Follow-up phone } \\
\text { calls made by blinded individuals. }\end{array}$ \\
\hline $\begin{array}{l}\text { Incomplete outcome data } \\
\text { (attrition bias) } \\
\text { All outcomes }\end{array}$ & Low risk & No losses to follow-up \\
\hline $\begin{array}{l}\text { Selective reporting (re- } \\
\text { porting bias) }\end{array}$ & Low risk & All outcomes reported. \\
\hline $\begin{array}{l}\text { Comparability of groups at } \\
\text { baseline }\end{array}$ & Low risk & Comparable \\
\hline
\end{tabular}

Niland 2006

\section{Study characteristics}

\begin{tabular}{ll}
\hline Methods & $\begin{array}{l}\text { Randomised, double-blind, 3-arm, prospective, placebo-controlled trial in an emergency department } \\
\text { setting in the USA. 5-day follow-up }\end{array}$ \\
\hline Participants & $\begin{array}{l}90 \text { participants (45 in each group) aged } 4 \text { to } 21 \text { years (median } 7.7 \text { years) with a positive direct strepto- } \\
\text { coccal antigen test }\end{array}$ \\
\hline Interventions & $\begin{array}{l}\text { Dexamethasone } 0.6 \text { mg/kg/day orally for } 1 \text { or } 3 \text { days versus oral placebo. } 45 \text { received IM and } 45 \text { re- } \\
\text { ceived oral antibiotics (type at discretion of physician). }\end{array}$ \\
\hline Outcomes & $\begin{array}{l}\text { Time to return of general health. Time to return of normal activity level. Days missed from school or } \\
\text { Pork. Time to complete pain resolution. Number with complete pain resolution at } 24 \text { and } 48 \text { hours. }\end{array}$ \\
\hline Notes & $\begin{array}{l}\text { Convenience sample. Analgesia use recorded. Funding source/declaration of interest: not declared. No } \\
\text { contact with study authors. }\end{array}$ \\
\hline
\end{tabular}

\section{Risk of bias}


Niland 2006 (Continued)

\begin{tabular}{|c|c|c|}
\hline Bias & Authors' judgement & Support for judgement \\
\hline $\begin{array}{l}\text { Random sequence genera- } \\
\text { tion (selection bias) }\end{array}$ & Low risk & Block randomisation in blocks of 9 , stratified by IM or oral antibiotics \\
\hline $\begin{array}{l}\text { Allocation concealment } \\
\text { (selection bias) }\end{array}$ & Low risk & Masked liquid suspension \\
\hline $\begin{array}{l}\text { Blinding (performance } \\
\text { bias and detection bias) } \\
\text { All outcomes }\end{array}$ & Low risk & $\begin{array}{l}\text { Participants and administering personnel blinded to the study drug. Blinding } \\
\text { of outcome assessor not explicitly stated. }\end{array}$ \\
\hline $\begin{array}{l}\text { Incomplete outcome data } \\
\text { (attrition bias) } \\
\text { All outcomes }\end{array}$ & Low risk & 6/90 lost to follow-up. \\
\hline $\begin{array}{l}\text { Selective reporting (re- } \\
\text { porting bias) }\end{array}$ & Low risk & All outcomes reported. \\
\hline $\begin{array}{l}\text { Comparability of groups at } \\
\text { baseline }\end{array}$ & Low risk & Comparable apart from gender - shown to have no influence on results \\
\hline
\end{tabular}

\section{O'Brien 1993}

\section{Study characteristics}

\begin{tabular}{|c|c|c|}
\hline Methods & \multicolumn{2}{|c|}{$\begin{array}{l}\text { Prospective, randomised, double-blind, placebo-controlled trial in an emergency department setting } \\
\text { in the USA. 7-day follow-up }\end{array}$} \\
\hline Participants & \multicolumn{2}{|c|}{$\begin{array}{l}58 \text { participants aged } 12 \text { to } 65 \text { years (mean } 26.3 \text { ) with visible tonsillar exudate, severe odynophagia or } \\
\text { dysphagia, and either fever or cervical adenopathy }\end{array}$} \\
\hline Interventions & \multicolumn{2}{|c|}{$\begin{array}{l}\text { Dexamethasone } 10 \mathrm{mg} \mathrm{IM} \mathrm{(10} \mathrm{mg/mL)} \mathrm{(} 31 \text { participants) or } 1 \mathrm{~mL} \text { saline IM ( } 27 \text { participants). 10-day } \\
\text { course of either penicillin V or erythromycin supplied to all participants. }\end{array}$} \\
\hline Outcomes & \multicolumn{2}{|c|}{ Reduction in pain VAS. Time to onset of pain relief. Time to complete pain resolution } \\
\hline Notes & \multicolumn{2}{|c|}{$\begin{array}{l}\text { Analgesia recorded but not regulated. Funding source/declaration of interest: not declared. No contact } \\
\text { with study authors. }\end{array}$} \\
\hline \multicolumn{3}{|l|}{ Risk of bias } \\
\hline Bias & Authors' judgement & Support for judgement \\
\hline $\begin{array}{l}\text { Random sequence genera- } \\
\text { tion (selection bias) }\end{array}$ & Low risk & Random numbers table \\
\hline $\begin{array}{l}\text { Allocation concealment } \\
\text { (selection bias) }\end{array}$ & Low risk & Syringes containing the 2 preparations were indistinguishable. \\
\hline $\begin{array}{l}\text { Blinding (performance } \\
\text { bias and detection bias) } \\
\text { All outcomes }\end{array}$ & Low risk & Physicians, nurses, and participants blinded to the study drug. \\
\hline
\end{tabular}


O'Brien 1993 (Continued)

Incomplete outcome data Unclear risk Primary outcome at 24 hours: $7 / 58$ lost to follow-up. Secondary outcome of (attrition bias) time to complete pain resolution: $32 / 58$ participants lost to follow-up

All outcomes

Selective reporting (re- $\quad$ Low risk $\quad$ All outcomes reported.
porting bias)

Comparability of groups at Low risk Comparable
baseline

\section{Olympia 2005}

\section{Study characteristics}

\begin{tabular}{ll} 
Methods & $\begin{array}{l}\text { Prospective, randomised, double-blind, placebo-controlled trial in an emergency department setting } \\
\text { in the USA. Follow-up until resolution of pain, longest contact with participant for follow-up was } 87 \\
\text { hours. }\end{array}$ \\
\hline Participants & $\begin{array}{l}150 \text { children (75 each group) aged } 5 \text { to } 18 \text { years (mean } 11.9 \text { years) with odynophagia or dysphagia, } \\
\text { moderate to severe pharyngeal erythema or swelling as determined by the emergency department } \\
\text { physician, and McGrath Facial Affective Scale (FAS) score of ' } F \text { ' (0.75) or higher were randomised. }\end{array}$ \\
\hline Interventions & $\begin{array}{l}\text { Dexamethasone } 0.6 \mathrm{mg} / \mathrm{kg} \text { orally single dose or oral isotonic sodium chloride solution as placebo. An- } \\
\text { tibiotics (penicillin } \mathrm{G} \mathrm{IM,} \mathrm{amoxicillin} \mathrm{or} \mathrm{azithromycin} \mathrm{orally)} \mathrm{given} \mathrm{if} \mathrm{rapid} \mathrm{streptococcal} \mathrm{antigen} \mathrm{test} \\
\text { positive or culture positive for group A beta-haemolytic streptococcus. }\end{array}$
\end{tabular}

$\begin{array}{ll}\text { Outcomes } & \text { Reduction in McGrath FAS score. Time to onset of pain relief. Time to complete pain resolution. Fever. } \\ \text { Associated symptoms. Need for further medical care }\end{array}$

\begin{tabular}{ll}
\hline Notes & Analgesia use recorded. Convenience sample of participants. Funding source/declaration of interest: \\
not declared. No contact with study authors.
\end{tabular}

\section{Risk of bias}

\begin{tabular}{lll}
\hline Bias & Authors' judgement & Support for judgement \\
\hline $\begin{array}{l}\text { Random sequence genera- } \\
\text { tion (selection bias) }\end{array}$ & Low risk & $\begin{array}{l}\text { Block randomisation using a computerised random numbers table in groups } \\
\text { of } 30\end{array}$ \\
\hline $\begin{array}{l}\text { Allocation concealment } \\
\text { (selection bias) }\end{array}$ & Low risk & $\begin{array}{l}\text { Both steroid and placebo medications flavoured and coloured with cherry } \\
\text { syrup. }\end{array}$ \\
\hline
\end{tabular}

Blinding (performance Low risk Double-blind design, although specific blinding not reported
bias and detection bias)
All outcomes

\begin{tabular}{|c|c|c|}
\hline $\begin{array}{l}\text { Incomplete outcome data } \\
\text { (attrition bias) } \\
\text { All outcomes }\end{array}$ & High risk & $25 / 150$ lost to follow-up. \\
\hline $\begin{array}{l}\text { Selective reporting (re- } \\
\text { porting bias) }\end{array}$ & Low risk & Abstract published 2 years earlier did not report any additional outcomes \\
\hline $\begin{array}{l}\text { Comparability of groups at } \\
\text { baseline }\end{array}$ & Unclear risk & Comparable \\
\hline
\end{tabular}


Tasar 2008

\section{Study characteristics}

\begin{tabular}{|c|c|c|}
\hline Methods & \multicolumn{2}{|c|}{$\begin{array}{l}\text { Prospective, randomised, double-blind, placebo-controlled trial in an emergency department setting } \\
\text { in Turkey }\end{array}$} \\
\hline Participants & \multicolumn{2}{|c|}{$\begin{array}{l}73 \text { participants aged } 18 \text { to } 65 \text { years (mean } 31.3 \text { years) with sore throat or odynophagia and } 2 \text { of the Cen- } \\
\text { tor criteria (absence of cough, tonsillar exudates, tender anterior cervical lymphadenopathy, fever) } \\
\text { were randomised to receive dexamethasone ( } 31 \text { participants) or placebo ( } 42 \text { participants). }\end{array}$} \\
\hline Interventions & \multicolumn{2}{|c|}{$\begin{array}{l}\text { Dexamethasone } 8 \mathrm{mg} \text { IM versus the same volume of saline IM. All participants received } 500 \mathrm{mg} \\
\text { azithromycin daily for } 3 \text { days. }\end{array}$} \\
\hline Outcomes & \multicolumn{2}{|c|}{$\begin{array}{l}\text { Time to onset of pain relief. Time to complete pain resolution. Percentage with complete pain resolu- } \\
\text { tion at } 24 \text { and } 48 \text { hours }\end{array}$} \\
\hline Notes & \multicolumn{2}{|c|}{$\begin{array}{l}\text { Paracetamol allowed for } 3 \text { days, unrecorded. Funding source/declaration of interest: not declared. No } \\
\text { contact with study authors. }\end{array}$} \\
\hline \multicolumn{3}{|l|}{ Risk of bias } \\
\hline Bias & Authors' judgement & Support for judgement \\
\hline $\begin{array}{l}\text { Random sequence genera- } \\
\text { tion (selection bias) }\end{array}$ & Low risk & Random number table \\
\hline $\begin{array}{l}\text { Allocation concealment } \\
\text { (selection bias) }\end{array}$ & Low risk & No visual difference between the drugs \\
\hline $\begin{array}{l}\text { Blinding (performance } \\
\text { bias and detection bias) } \\
\text { All outcomes }\end{array}$ & Low risk & $\begin{array}{l}\text { Physicians administering the drugs were blinded to the contents. No comment } \\
\text { on blinding of outcome assessors. However, drugs were prepared and ran- } \\
\text { domised by the pharmacy. }\end{array}$ \\
\hline $\begin{array}{l}\text { Incomplete outcome data } \\
\text { (attrition bias) } \\
\text { All outcomes }\end{array}$ & Low risk & No loss to follow-up \\
\hline $\begin{array}{l}\text { Selective reporting (re- } \\
\text { porting bias) }\end{array}$ & Low risk & All intended outcomes reported. \\
\hline $\begin{array}{l}\text { Comparability of groups at } \\
\text { baseline }\end{array}$ & Unclear risk & Comparable \\
\hline
\end{tabular}

Wei 2002

\section{Study characteristics}

Methods

Randomised, double-blind, 3-arm, placebo-controlled trial in an emergency department setting in the USA. 24-hour follow-up, but contact of participants with healthcare services monitored at day 5.

\section{Participants}

118 participants aged 15 years or more (mean age 28 years) with clinical diagnosis of acute pharyngitis or tonsillitis and pharyngeal erythema with or without exudate 
Wei 2002 (Continued)

1. $10 \mathrm{mg} \mathrm{IM} \mathrm{dexamethasone} \mathrm{and} \mathrm{placebo} \mathrm{tablet} \mathrm{(39} \mathrm{participants)}$

2. $10 \mathrm{mg}$ oral dexamethasone and IM placebo (42 participants)

3. IM and oral placebo (37 participants)

Outcomes

Reduction in pain VAS. Percentage with complete pain resolution at 24 hours. Time to return to normal activity. Ability to take liquids and solids. Percentage recurrence

Notes Paracetamol allowed for the first 24 hours as required; usage recorded. Funding source/declaration of interest: not declared. No contact with study authors.

\section{Risk of bias}

\begin{tabular}{lll}
\hline Bias & Authors' judgement & Support for judgement \\
\hline $\begin{array}{l}\text { Random sequence genera- } \\
\text { tion (selection bias) }\end{array}$ & Low risk & $\begin{array}{l}\text { Randomisation scheme prepared by section of biostatistics and held by a cen- } \\
\text { tral pharmacy. }\end{array}$ \\
\hline $\begin{array}{l}\text { Allocation concealment } \\
\text { (selection bias) }\end{array}$ & Unclear risk & Not specifically mentioned. \\
\hline $\begin{array}{l}\text { Blinding (performance } \\
\text { bias and detection bias) } \\
\text { All outcomes }\end{array}$ & Low risk & $\begin{array}{l}\text { Physician administering the treatment was blinded to the content. Blinding of } \\
\text { outcome assessor not specifically commented upon. }\end{array}$ \\
\hline $\begin{array}{l}\text { Incomplete outcome data } \\
\text { (attrition bias) } \\
\begin{array}{l}\text { All outcomes } \\
\text { Selective reporting (re- }\end{array}\end{array}$ & Low risk \\
$\begin{array}{l}\text { porting bias) } \\
\begin{array}{l}\text { Comparability of groups at } \\
\text { baseline }\end{array}\end{array}$ & Low risk & $\begin{array}{l}7 / 118 \text { participants did not provide 12-hour follow-up. 2/118 participants did } \\
\text { not provide 24-hour follow-up. }\end{array}$ \\
\hline
\end{tabular}

FAS: facial affective scale

IM: intramuscular

VAS: visual analogue scale

Characteristics of excluded studies [ordered by study ID]

\begin{tabular}{ll}
\hline Study & Reason for exclusion \\
\hline Ahn 2003 & Not randomised \\
\hline Armstrong 2018 & Systematic review \\
\hline Chen 2018 & Steroids were given to both study arms. \\
\hline Chenot 2018 & Systematic review \\
\hline Hahn 1951 & Hospitalised participants \\
\hline Hristea 2013 & Summary of systematic review \\
\hline Marvez-Valls 2002 & No placebo or usual care control group
\end{tabular}




\begin{tabular}{ll}
\hline Study & Reason for exclusion \\
\hline Shaughnessy 2018 & Systematic review \\
\hline Welch 2014 & Systematic review \\
\hline
\end{tabular}

Characteristics of ongoing studies [ordered by study ID]

\section{ACTRN12618000017224}

\begin{tabular}{ll}
\hline Study name & Use of oral prednisone in acute sore throats \\
\hline Methods & RCT: patients with sore throat will be randomised into 2 groups. 1 group will receive 40 mg pred- \\
& nisone administered daily for 2 days, and the other will be given placebo tablets (microcellulose \\
& tablets) taken for the same period of time. Participants will be contacted at 48 hours for sympto- \\
& matic scoring and asked to return a pain diary. All participants will be swabbed to rule out Group A \\
& strep infection. Where throat swabs are noted to be positive (generally after 48 hours), these partic- \\
& ipants would be treated appropriately with antibiotics.
\end{tabular}

\begin{tabular}{ll}
\hline Participants & Aged 16 years and over with sore throat occurring within the last 7 days \\
\hline Interventions & 40 mg prednisone \\
\hline Outcomes & $\begin{array}{l}\text { Primary outcome: assessment of sore throat pain by a VAS in a symptom diary provided to the par- } \\
\text { ticipant, symptom diary review of the time of resolution of pain symptoms noted by the enrolled } \\
\text { participants, resolution of throat pain (yes/no) as defined by a score of less than } 2 \text { on a VAS. Se- } \\
\text { condary outcomes: time to return to normal activities as assessed by phon } \\
\text { diaries collected, adverse events }\end{array}$ \\
\hline Starting date & 1 February 2018 \\
\hline Contact information & Dr Ivan Koay, Silverdale Medical Centre Auckland \\
\hline Notes & \\
\hline
\end{tabular}

\section{ACTRN12618000847213}

\begin{tabular}{ll}
\hline Study name & Efficacy of single dose dexamethasone in the management of sore throat \\
\hline Methods & $\begin{array}{l}\text { RCT: patients with sore throat due to viral aetiology will be randomised into } 2 \text { groups. } 1 \text { group will } \\
\text { receive single dose oral (tablet) dexamethasone }(10 \mathrm{mg}) \text { and symptomatic treatment, whilst the } \\
\text { other group will be given symptomatic treatment only. The medication will be given in the health } \\
\text { centre under direct observation of the study personnel. The symptomatic treatment includes anti- } \\
\text { histamine and antipyretics. }\end{array}$
\end{tabular}

\begin{tabular}{ll}
\hline Participants & Adults aged over 18 years old presenting with sore throat will be invited to take part in the study. \\
\hline Interventions & $10 \mathrm{mg}$ dexamethasone \\
\hline Outcomes & $\begin{array}{l}\text { Primary outcome: change in participant subjective rating of pain using a VAS. Secondary outcomes: } \\
\text { time to complete symptom resolution (VAS }=0), \text { need for antibiotics up to } 7 \text { days post-treatment, } \\
\text { side effect of the studied medication }\end{array}$ \\
\hline
\end{tabular}


ACTRN12618000847213 (Continued)

Contact information

Dr Asma Al Salmani, Muscat College of Medicine and Health Sciences

Notes

RCT: randomised controlled trial

VAS: visual analogue scale

\section{DATA AND ANALYSES}

Comparison 1. Corticosteroids versus placebo

\begin{tabular}{|c|c|c|c|c|}
\hline Outcome or subgroup title & No. of studies & $\begin{array}{l}\text { No. of partici- } \\
\text { pants }\end{array}$ & Statistical method & Effect size \\
\hline $\begin{array}{l}1.1 \text { Complete resolution of pain at } \\
24 \text { hours }\end{array}$ & 5 & 851 & $\begin{array}{l}\text { Risk Ratio (M-H, Random, 95\% } \\
\mathrm{Cl})\end{array}$ & $2.40[1.29,4.47]$ \\
\hline $\begin{array}{l}1.2 \text { Complete resolution of pain at } \\
24 \text { hours: route of corticosteroid ad- } \\
\text { ministration }\end{array}$ & 5 & & $\begin{array}{l}\text { Risk Ratio (M-H, Random, 95\% } \\
\mathrm{Cl})\end{array}$ & Subtotals only \\
\hline 1.2.1 Oral & 4 & 778 & $\begin{array}{l}\text { Risk Ratio (M-H, Random, 95\% } \\
\mathrm{Cl})\end{array}$ & $1.88[1.13,3.14]$ \\
\hline 1.2.2 Intramuscular & 2 & 148 & $\begin{array}{l}\text { Risk Ratio (M-H, Random, 95\% } \\
\mathrm{Cl} \text { ) }\end{array}$ & $4.59[1.62,13.03]$ \\
\hline $\begin{array}{l}1.3 \text { Complete resolution of pain at } \\
48 \text { hours }\end{array}$ & 4 & 774 & $\begin{array}{l}\text { Risk Ratio (M-H, Random, 95\% } \\
\mathrm{Cl})\end{array}$ & $1.50[1.27,1.76]$ \\
\hline 1.4 Mean time to onset of pain relief & 7 & 840 & $\begin{array}{l}\text { Mean Difference (IV, Random, } \\
95 \% \mathrm{CI})\end{array}$ & $-5.96[-8.75,-3.17]$ \\
\hline $\begin{array}{l}1.5 \text { Mean time to onset of pain relief } \\
\text { by bacterial pathogen positive/neg- } \\
\text { ative }\end{array}$ & 5 & & $\begin{array}{l}\text { Mean Difference (IV, Random, } \\
95 \% \mathrm{CI})\end{array}$ & Subtotals only \\
\hline 1.5.1 Bacterial pathogen positive & 5 & 243 & $\begin{array}{l}\text { Mean Difference (IV, Random, } \\
95 \% \mathrm{CI})\end{array}$ & $-5.49[-8.19,-2.79]$ \\
\hline 1.5.2 Bacterial pathogen negative & 5 & 422 & $\begin{array}{l}\text { Mean Difference (IV, Random, } \\
95 \% \mathrm{CI})\end{array}$ & $-3.15[-7.63,1.33]$ \\
\hline $\begin{array}{l}1.6 \text { Mean time to onset of pain re- } \\
\text { lief in exudative/not exudative sore } \\
\text { throat }\end{array}$ & 4 & & $\begin{array}{l}\text { Mean Difference (IV, Random, } \\
95 \% \mathrm{CI})\end{array}$ & Subtotals only \\
\hline 1.6.1 Exudative & 2 & 150 & $\begin{array}{l}\text { Mean Difference (IV, Random, } \\
95 \% \mathrm{CI})\end{array}$ & $-5.49[-7.96,-3.02]$ \\
\hline 1.6.2 Not exudative & 2 & 261 & $\begin{array}{l}\text { Mean Difference (IV, Random, } \\
95 \% \mathrm{CI})\end{array}$ & $-3.05[-7.04,0.93]$ \\
\hline
\end{tabular}




\begin{tabular}{|c|c|c|c|c|}
\hline Outcome or subgroup title & No. of studies & $\begin{array}{l}\text { No. of partici- } \\
\text { pants }\end{array}$ & Statistical method & Effect size \\
\hline $\begin{array}{l}1.7 \text { Mean time to onset of pain relief } \\
\text { in severe/not severe sore throat }\end{array}$ & 6 & & $\begin{array}{l}\text { Mean Difference (IV, Random, } \\
95 \% \mathrm{CI})\end{array}$ & Subtotals only \\
\hline 1.7.1 Severe sore throat & 2 & 183 & $\begin{array}{l}\text { Mean Difference (IV, Random, } \\
95 \% \mathrm{CI})\end{array}$ & $\begin{array}{l}-7.19[-10.12 \\
-4.27]\end{array}$ \\
\hline $\begin{array}{l}\text { 1.7.2 Trials not selecting only partic- } \\
\text { ipants with severe sore throat }\end{array}$ & 4 & 423 & $\begin{array}{l}\text { Mean Difference (IV, Random, } \\
95 \% \mathrm{CI})\end{array}$ & $\begin{array}{l}-5.74[-10.12 \\
-1.36]\end{array}$ \\
\hline $\begin{array}{l}1.8 \text { Mean time to onset of pain relief } \\
\text { by route of corticosteroid adminis- } \\
\text { tration }\end{array}$ & 7 & & $\begin{array}{l}\text { Mean Difference (IV, Random, } \\
95 \% \mathrm{CI})\end{array}$ & Subtotals only \\
\hline 1.8.1 Oral corticosteroids & 4 & 617 & $\begin{array}{l}\text { Mean Difference (IV, Random, } \\
95 \% \mathrm{CI})\end{array}$ & $-4.39[-7.87,-0.92]$ \\
\hline 1.8.2 Intramuscular corticosteroids & 4 & 297 & $\begin{array}{l}\text { Mean Difference (IV, Random, } \\
95 \% \mathrm{CI})\end{array}$ & $\begin{array}{l}-6.94[-10.27 \\
-3.61]\end{array}$ \\
\hline $\begin{array}{l}1.9 \text { Mean time to complete resolu- } \\
\text { tion of pain }\end{array}$ & 6 & 695 & $\begin{array}{l}\text { Mean Difference (IV, Random, } \\
95 \% \mathrm{CI})\end{array}$ & $\begin{array}{l}-11.62[-22.17 \\
-1.08]\end{array}$ \\
\hline $\begin{array}{l}\text { 1.10 Mean absolute reduction in } \\
\text { pain VAS/McGrath scale at } 24 \text { hours }\end{array}$ & 7 & 1004 & $\begin{array}{l}\text { Mean Difference (IV, Random, } \\
95 \% \mathrm{CI} \text { ) }\end{array}$ & $1.06[0.21,1.92]$ \\
\hline 1.11 Adverse events & 2 & 690 & $\begin{array}{l}\text { Risk Ratio (M-H, Random, 95\% } \\
\text { Cl) }\end{array}$ & $1.08[0.31,3.77]$ \\
\hline 1.12 Relapse rates of symptoms & 3 & 353 & $\begin{array}{l}\text { Risk Ratio (M-H, Random, 95\% } \\
\mathrm{Cl})\end{array}$ & $0.52[0.16,1.73]$ \\
\hline $\begin{array}{l}\text { 1.13 Days missed from work or } \\
\text { school }\end{array}$ & 2 & 405 & $\begin{array}{l}\text { Mean Difference (IV, Random, } \\
95 \% \mathrm{CI} \text { ) }\end{array}$ & $-0.28[-0.84,0.28]$ \\
\hline
\end{tabular}

\section{Analysis 1.1. Comparison 1: Corticosteroids versus placebo, Outcome 1: Complete resolution of pain at 24 hours}

\begin{tabular}{|c|c|c|c|c|c|c|c|c|}
\hline \multirow[b]{2}{*}{ Study or Subgroup } & \multicolumn{2}{|c|}{ Corticosteroid } & \multicolumn{2}{|c|}{ Placebo } & \multirow[b]{2}{*}{ Weight } & Risk Ratio & \multirow{2}{*}{\multicolumn{2}{|c|}{$\begin{array}{c}\text { Risk Ratio } \\
\text { M-H, Random, 95\% CI }\end{array}$}} \\
\hline & Events & Total & Events & Total & & M-H, Random, 95\% CI & & \\
\hline Tasar 2008 & 13 & 31 & 2 & 42 & $12.2 \%$ & $8.81[2.14,36.23]$ & & $\longrightarrow$ \\
\hline Wei 2002 & 12 & 41 & 4 & 36 & $17.2 \%$ & $2.63[0.93,7.45]$ & & $=$ \\
\hline Kiderman 2005 & 17 & 40 & 4 & 39 & $17.9 \%$ & $4.14[1.53,11.22]$ & & $\longrightarrow$ \\
\hline Niland 2006 & 12 & 27 & 8 & 30 & $22.7 \%$ & $1.67[0.80,3.45]$ & & $\rightarrow-$ \\
\hline Hayward 2017 & 65 & 288 & 49 & 277 & $30.1 \%$ & $1.28[0.92,1.78]$ & & 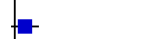 \\
\hline Total (95\% CI) & & 427 & & 424 & $100.0 \%$ & $2.40[1.29,4.47]$ & & \\
\hline Total events: & 119 & & 67 & & & & & \\
\hline \multicolumn{7}{|c|}{ Heterogeneity: $\mathrm{Tau}^{2}=0.31 ; \mathrm{Chi}^{2}=12.05, \mathrm{df}=4(\mathrm{P}=0.02) ; \mathrm{I}^{2}=67 \%$} & $0.01 \quad 0.1$ & 10 \\
\hline \multicolumn{7}{|c|}{ Test for overall effect: $\mathrm{Z}=2.75(\mathrm{P}=0.006)$} & Favours placebo & Favours \\
\hline
\end{tabular}


Analysis 1.2. Comparison 1: Corticosteroids versus placebo, Outcome 2: Complete resolution of pain at 24 hours: route of corticosteroid administration

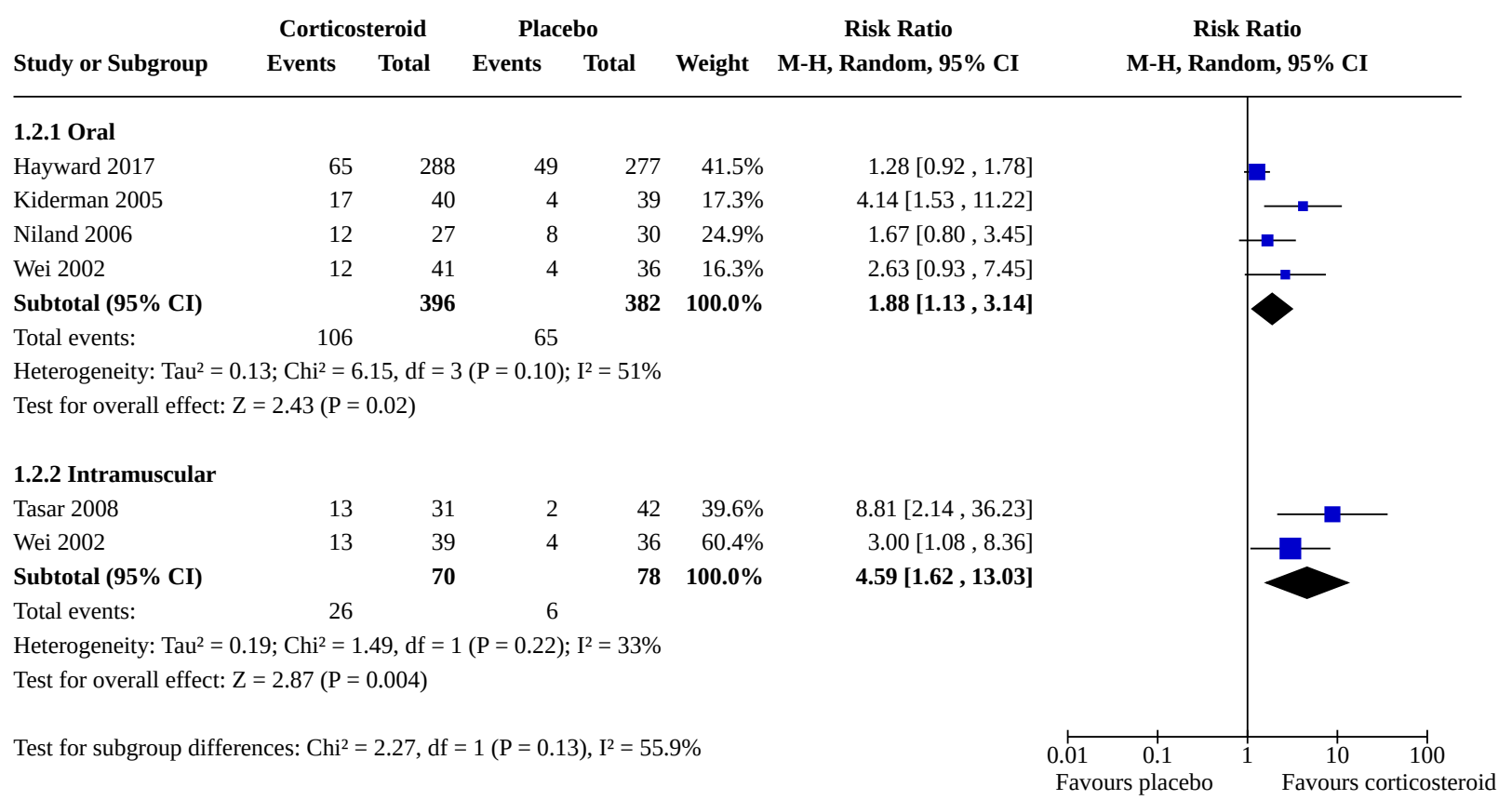

\section{Analysis 1.3. Comparison 1: Corticosteroids versus placebo, Outcome 3: Complete resolution of pain at 48 hours}

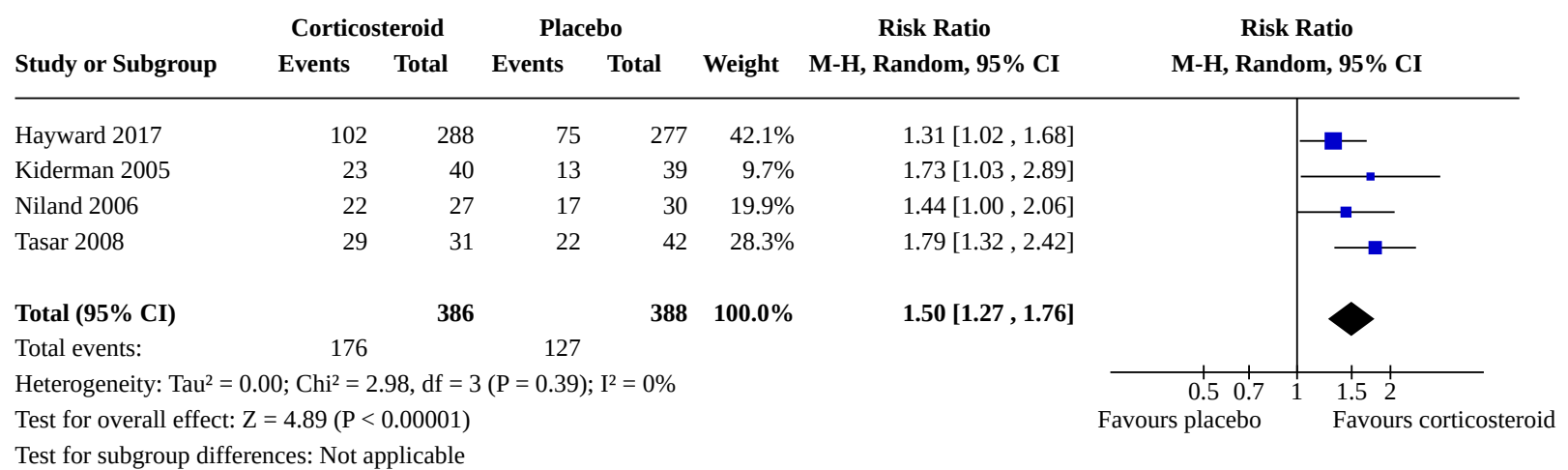


Analysis 1.4. Comparison 1: Corticosteroids versus placebo, Outcome 4: Mean time to onset of pain relief

\begin{tabular}{|c|c|c|c|c|c|c|c|c|c|c|}
\hline \multirow[b]{2}{*}{ Study or Subgroup } & \multicolumn{3}{|c|}{ Corticosteroid } & \multicolumn{3}{|c|}{ Placebo } & \multicolumn{2}{|r|}{ Mean Difference } & \multicolumn{2}{|c|}{ Mean Difference } \\
\hline & Mean & SD & Total & Mean & SD & Total & Weight & IV, Random, 95\% CI & IV, Randol & om, $95 \%$ CI \\
\hline Bulloch 2003 & 9.6 & 19.4 & 92 & 10.1 & 15.6 & 92 & $12.6 \%$ & $-0.50[-5.59,4.59]$ & & \\
\hline Hayward 2017 & 37.5 & 26 & 129 & 39.77 & 28.7 & 102 & $8.9 \%$ & $-2.27[-9.42,4.88]$ & & \\
\hline Marvez-Valls 1998 & 6.3 & 8.1 & 46 & 11.3 & 8.1 & 46 & $16.5 \%$ & $-5.00[-8.31,-1.69]$ & - & \\
\hline O'Brien 1993 & 6.3 & 5.3 & 31 & 12.4 & 8.5 & 27 & $15.6 \%$ & $-6.10[-9.81,-2.39]$ & - & \\
\hline Olympia 2005 & 9.2 & 7.5 & 57 & 18.2 & 18.3 & 68 & $13.2 \%$ & $-9.00[-13.77,-4.23]$ & - & \\
\hline Tasar 2008 & 8.1 & 4.9 & 31 & 19.9 & 9.4 & 42 & $16.5 \%$ & $-11.80[-15.13,-8.47]$ & $\multimap-$ & \\
\hline Wei 2002 & 7.4 & 5.3 & 42 & 12.07 & 8.7 & 35 & $16.6 \%$ & $-4.67[-7.97,-1.37]$ & $\multimap$ & \\
\hline Total (95\% CI) & & & 428 & & & 412 & $100.0 \%$ & $-5.96[-8.75,-3.17]$ & & \\
\hline \multicolumn{11}{|c|}{ Heterogeneity: $\mathrm{Tau}^{2}=9.42 ; \mathrm{Chi}^{2}=19.49, \mathrm{df}=6(\mathrm{P}=0.003) ; \mathrm{I}^{2}=69 \%$} \\
\hline \multicolumn{9}{|c|}{ Test for overall effect: $\mathrm{Z}=4.18(\mathrm{P}<0.0001)$} & $\frac{1}{-20}$ & 10 \\
\hline
\end{tabular}
Analysis 1.5. Comparison 1: Corticosteroids versus placebo, Outcome 5:
Mean time to onset of pain relief by bacterial pathogen positive/negative

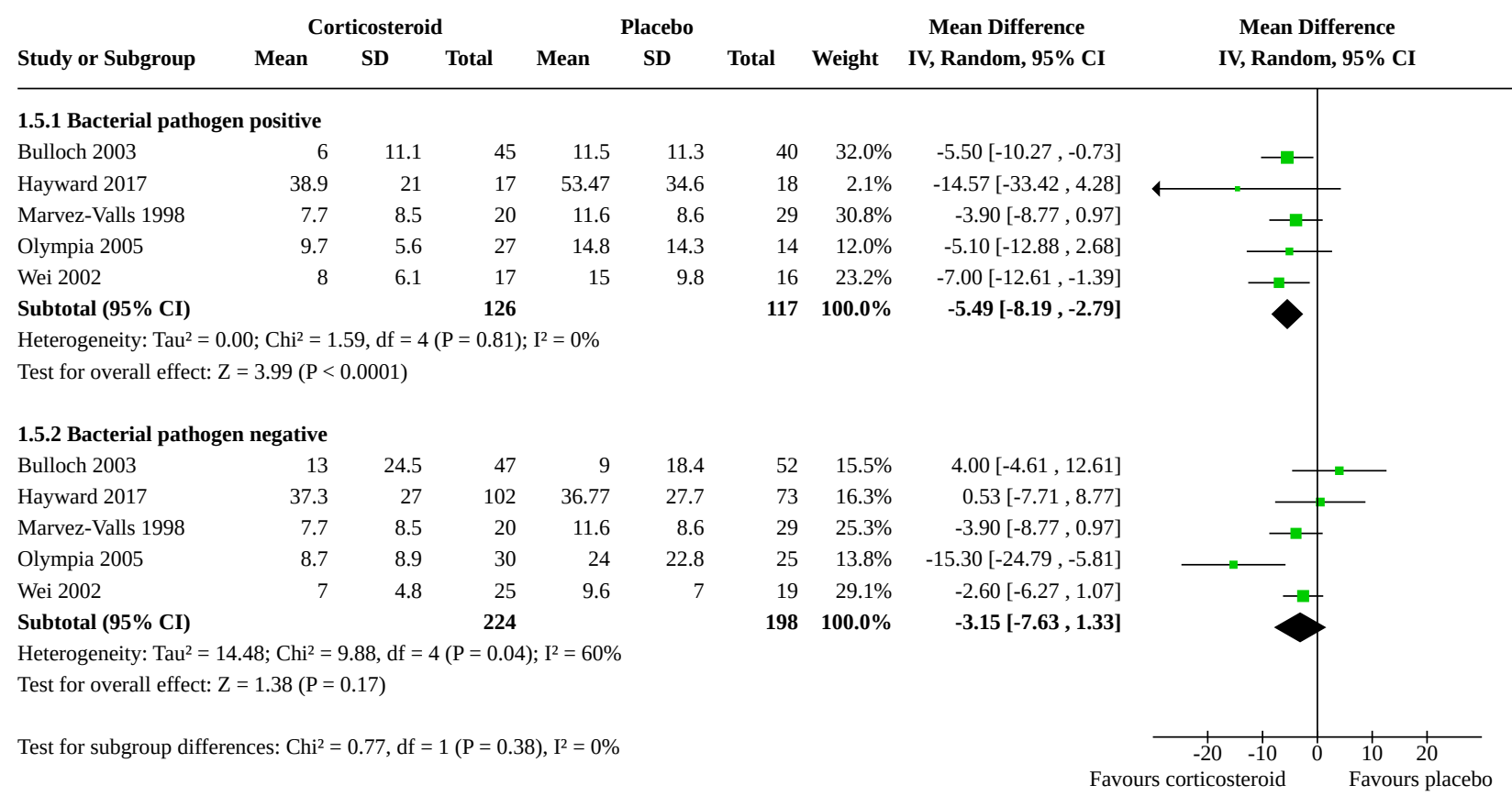


Analysis 1.6. Comparison 1: Corticosteroids versus placebo, Outcome 6: Mean time to onset of pain relief in exudative/not exudative sore throat

\begin{tabular}{|c|c|c|c|c|c|c|c|c|c|}
\hline & \multicolumn{3}{|c|}{ Corticosteroid } & \multicolumn{3}{|c|}{ Placebo } & \multicolumn{2}{|r|}{ Mean Difference } & Mean Difference \\
\hline Study or Subgroup & Mean & SD & Total & Mean & SD & Total & Weight & IV, Random, 95\% CI & IV, Random, 95\% CI \\
\hline
\end{tabular}

\subsubsection{Exudative}

Marvez-Valls 1998

O'Brien 1993

SD Total Mean

SD

Weight IV, Random, 95\% CI

V, Random, 95\% CI

Subtotal (95\% CI)

$\begin{array}{llll}6.3 & 8.1 & 46 & 11.3\end{array}$

8.1

$\begin{array}{ll}46 & 55.7 \% \\ 27 & 44.3 \%\end{array}$

$-5.00[-8.31,-1.69]$

Heterogeneity: $\mathrm{Tau}^{2}=0.00 ; \mathrm{Chi}^{2}=0.19, \mathrm{df}=1(\mathrm{P}=0.66) ; \mathrm{I}^{2}=0 \%$

$73 \quad \mathbf{1 0 0 . 0} \%$

-6.10 [-9.81, - -2.39]

$-5.49[-7.96,-3.02]$

Test for overall effect: $\mathrm{Z}=4.35(\mathrm{P}<0.0001)$

1.6.2 Not exudative

Bulloch 2003

Wei 2002

$\begin{array}{rrrr}9.6 & 19.4 & 92 & 10.1 \\ 7.4 & 5.3 & 42 & 12.07\end{array}$

Subtotal (95\% CI)

134

Heterogeneity: $\mathrm{Tau}^{2}=3.91 ; \mathrm{Chi}^{2}=1.82, \mathrm{df}=1(\mathrm{P}=0.18) ; \mathrm{I}^{2}=45 \%$

Test for overall effect: $\mathrm{Z}=1.50(\mathrm{P}=0.13)$

Test for subgroup differences: $\mathrm{Chi}^{2}=1.04, \mathrm{df}=1(\mathrm{P}=0.31), \mathrm{I}^{2}=3.6 \%$

$\begin{array}{rrrr}15.6 & 92 & 38.8 \% & -0.50[-5.59,4.59] \\ 8.7 & 35 & 61.2 \% & -4.67[-7.97,-1.37] \\ & \mathbf{1 2 7} & \mathbf{1 0 0 . 0 \%} & \mathbf{- 3 . 0 5}[-\mathbf{- 7 . 0 4}, \mathbf{0 . 9 3}]\end{array}$
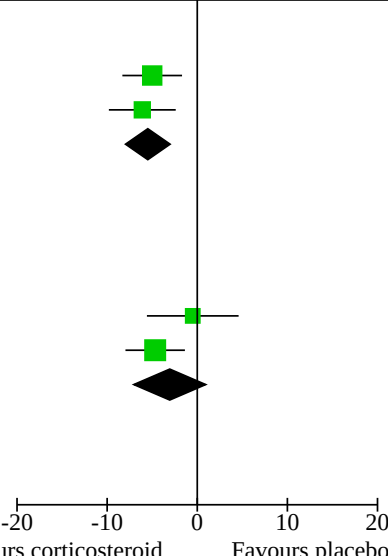

\section{Analysis 1.7. Comparison 1: Corticosteroids versus placebo, Outcome 7: Mean time to onset of pain relief in severe/not severe sore throat}

\begin{tabular}{|c|c|c|c|c|c|c|c|c|c|}
\hline \multirow{2}{*}{ Study or Subgroup } & \multicolumn{3}{|c|}{ Corticosteroid } & \multicolumn{3}{|c|}{ Placebo } & \multicolumn{2}{|r|}{ Mean Difference } & Mean Difference \\
\hline & Mean & SD & Total & Mean & SD & Total & Weight & IV, Random, 95\% CI & IV, Random, 95\% CI \\
\hline
\end{tabular}

1.7.1 Severe sore throat

$\begin{array}{lllllrlrr}\text { O'Brien } 1993 & 6.3 & 5.3 & 31 & 12.4 & 8.5 & 27 & 62.3 \% & -6.10[-9.81,-2.39] \\ \text { Olympia 2005 } & 9.2 & 7.5 & 57 & 18.2 & 18.3 & 68 & 37.7 \% & \mathbf{- 9 . 0 0 [ - 1 3 . 7 7 , - 4 . 2 3 ]} \\ \text { Subtotal (95\% CI) } & & & \mathbf{8 8} & & & \mathbf{9 5} & \mathbf{1 0 0 . 0 \%} & \mathbf{- 7 . 1 9}[\mathbf{- 1 0 . 1 2}, \mathbf{- 4 . 2 7}]\end{array}$

Heterogeneity: $\mathrm{Tau}^{2}=0.00 ; \mathrm{Chi}^{2}=0.89, \mathrm{df}=1(\mathrm{P}=0.35) ; \mathrm{I}^{2}=0 \%$

$95 \quad 100.0 \% \quad-7.19[-10.12,-4.27]$

Test for overall effect: $\mathrm{Z}=4.82(\mathrm{P}<0.00001)$

1.7.2 Trials not selecting only participants with severe sore throat

$\begin{array}{lrrrrrrrr}\text { Bulloch 2003 } & 9.6 & 19.4 & 92 & 10.1 & 15.6 & 92 & 21.8 \% & -0.50[-5.59,4.59] \\ \text { Marvez-Valls 1998 } & 6.3 & 8.1 & 46 & 11.3 & 8.1 & 46 & 26.2 \% & -5.00[-8.31,-1.69] \\ \text { Tasar 2008 } & 8.1 & 4.9 & 31 & 19.9 & 9.4 & 42 & 26.2 \% & -11.80[-15.13,-8.47] \\ \text { Wei 2002 } & 7.23 & 6.01 & 39 & 12 & 8.7 & 35 & 25.9 \% & -4.77[-8.21,-1.33] \\ \text { Subtotal (95\% CI) } & & & \mathbf{2 0 8} & & & \mathbf{2 1 5} & \mathbf{1 0 0 . 0 \%} & \mathbf{- 5 . 7 4 [ - 1 0 . 1 2 , - 1 . 3 6}\end{array}$

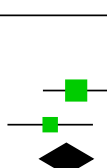

Heterogeneity: $\mathrm{Tau}^{2}=16.22 ; \mathrm{Chi}^{2}=16.85, \mathrm{df}=3(\mathrm{P}=0.0008) ; \mathrm{I}^{2}=82 \%$

Test for overall effect: $\mathrm{Z}=2.57(\mathrm{P}=0.01)$

Test for subgroup differences: $\mathrm{Chi}^{2}=0.29, \mathrm{df}=1(\mathrm{P}=0.59), \mathrm{I}^{2}=0 \%$

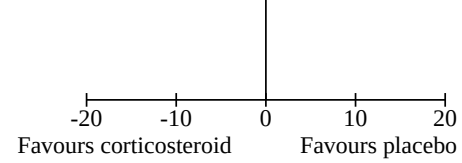


Analysis 1.8. Comparison 1: Corticosteroids versus placebo, Outcome 8: Mean time to onset of pain relief by route of corticosteroid administration

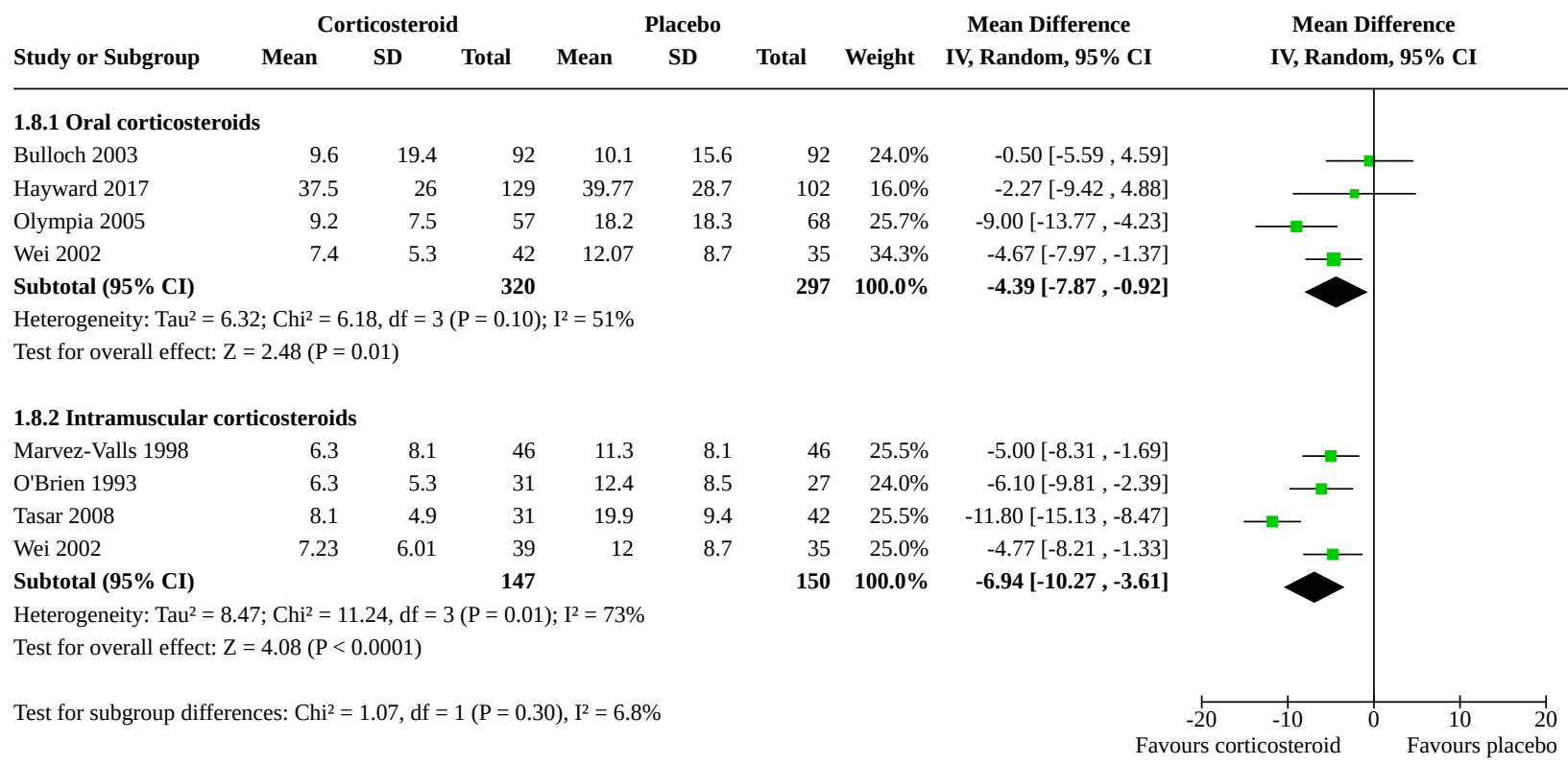

Analysis 1.9. Comparison 1: Corticosteroids versus placebo, Outcome 9: Mean time to complete resolution of pain

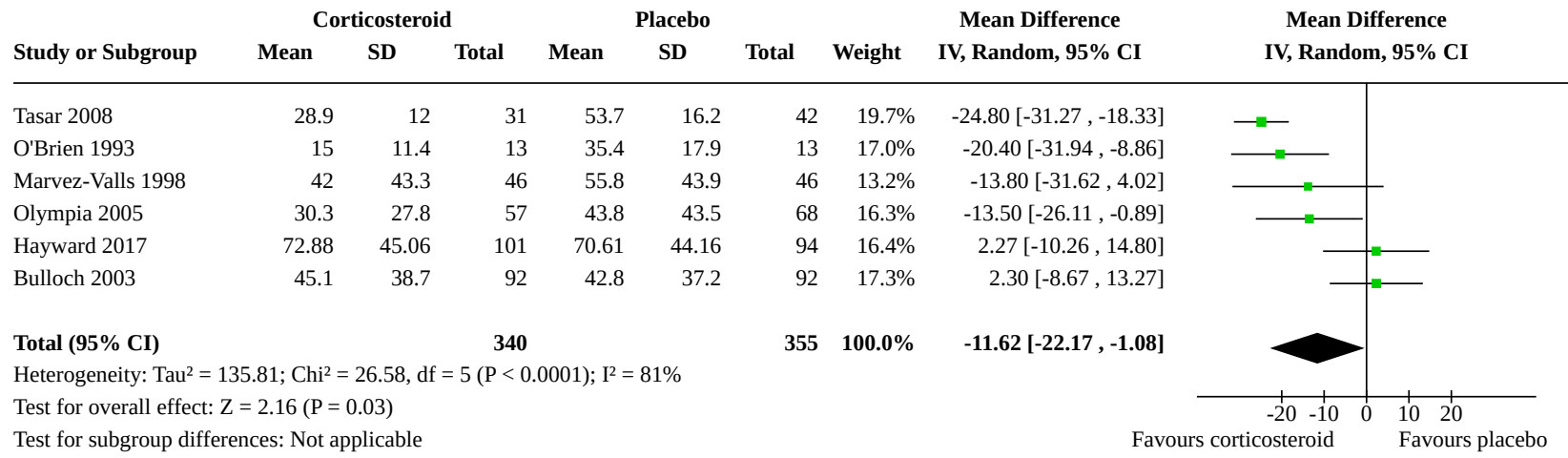

Test for subgroup differences: Not applicable

Analysis 1.10. Comparison 1: Corticosteroids versus placebo, Outcome 10: Mean absolute reduction in pain VAS/McGrath scale at 24 hours

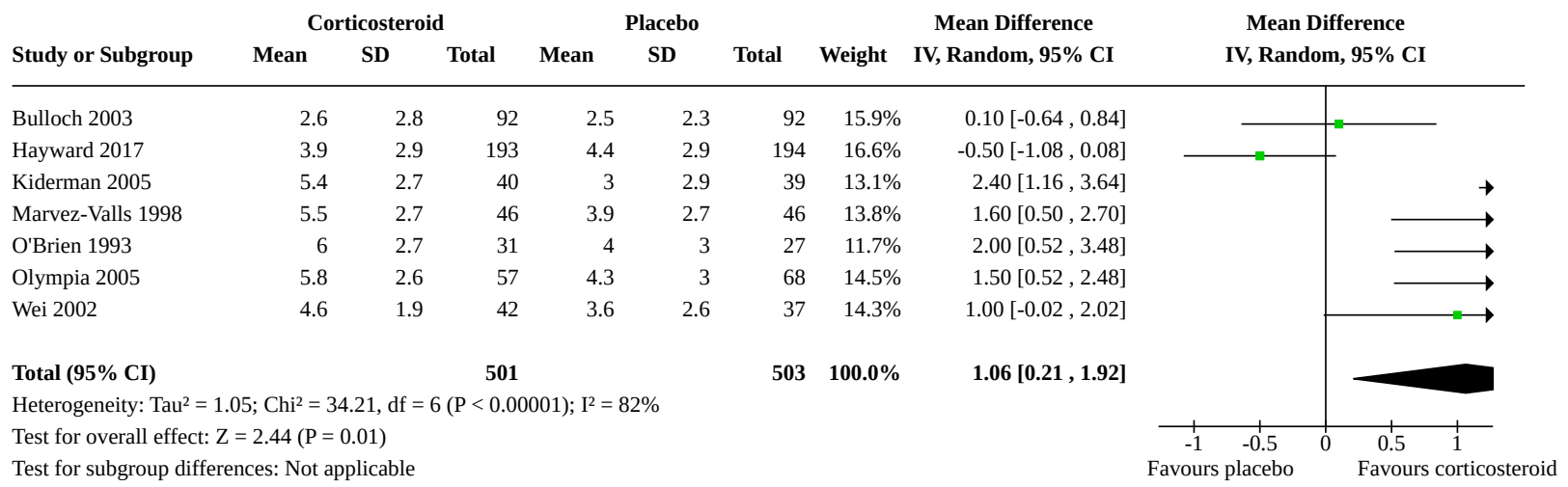




\section{Analysis 1.11. Comparison 1: Corticosteroids versus placebo, Outcome 11: Adverse events}

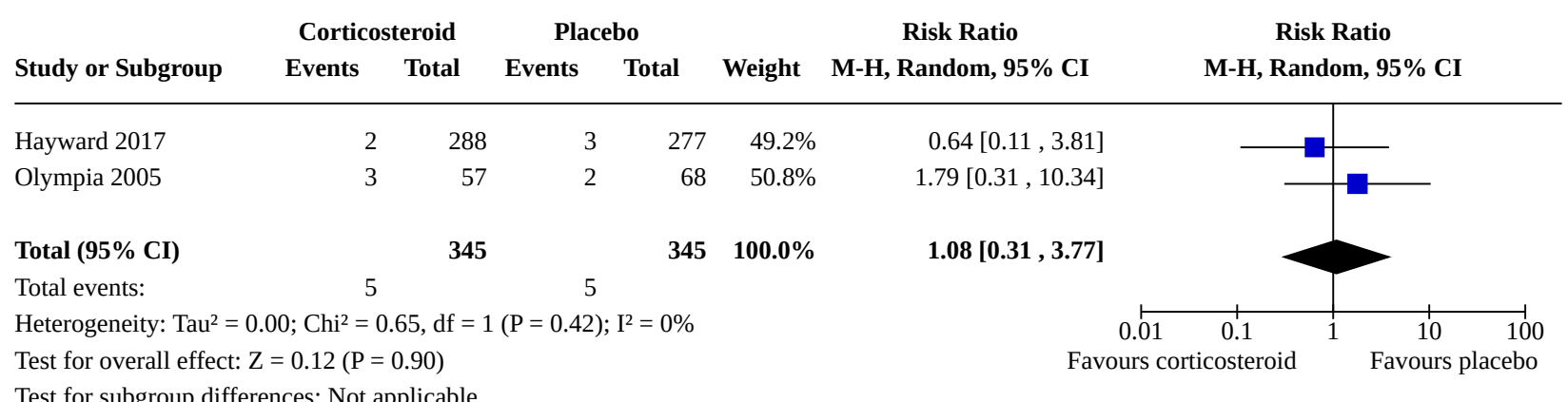

\section{Analysis 1.12. Comparison 1: Corticosteroids versus placebo, Outcome 12: Relapse rates of symptoms}

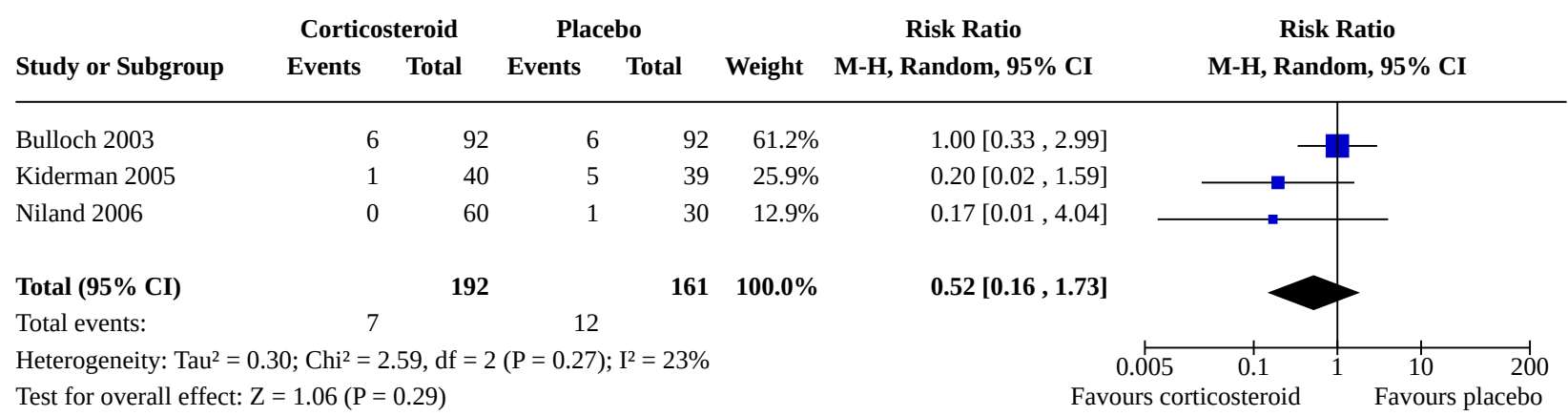

Test for subgroup differences: Not applicable

Analysis 1.13. Comparison 1: Corticosteroids versus placebo, Outcome 13: Days missed from work or school

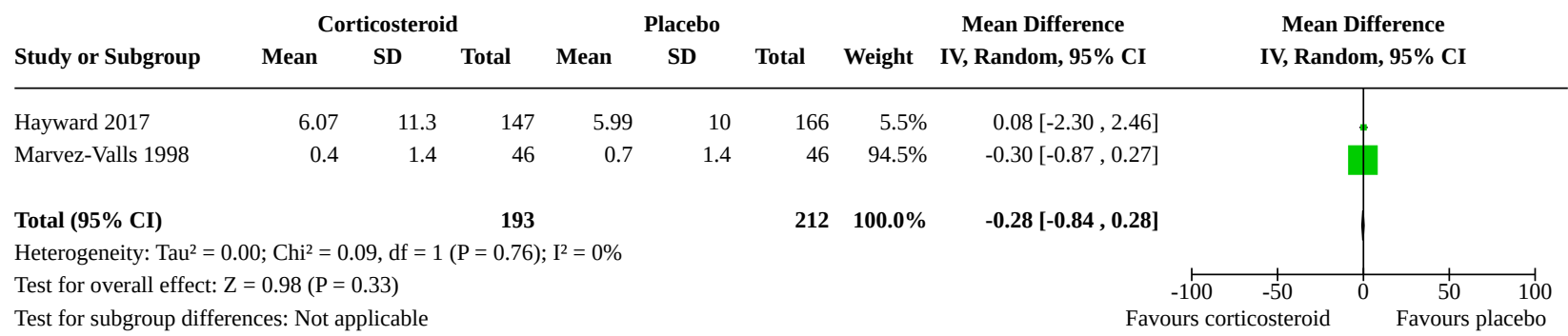

\section{AP P E N DICES}

\section{Appendix 1. MEDLINE (via Ovid) and CENTRAL search strategy}

1 exp Tonsillitis/

2 tonsillit*.tw.

3 exp Pharyngitis/

4 pharyngit*.tw.

5 exp Laryngitis/

6 laryngit ${ }^{\star}$. tw.

7 pharyngotonsillit*.tw.

8 sore throat ${ }^{\star}$. tw. 
9 exp Streptococcus/

10 Streptococcal Infections/

11 (streptococc* or gabhs).tw.

12 ("s. pyogenes" or "s pyogenes").tw.

13 ("s. pneumoniae" or "s pneumoniae").tw.

14 or/1-13

15 exp Glucocorticoids/

16 glucocorticoid ${ }^{\star}$.tw, nm.

17 exp Hydroxycorticosteroids/

18 hydroxycorticosteroid ${ }^{\star}$. tw, nm.

19 exp Pregnenediones/

20 hydrocortisone.tw, nm.

21 hydroxypregnenolone.tw, nm.

22 pregnenolone.tw, nm.

23 tetrahydrocortisol.tw,nm.

24 cortodoxone.tw, nm.

25 cortisone.tw, nm.

26 corticosterone.tw, nm.

27 triamcinolone.tw, nm.

28 prednisone.tw, nm.

29 prednisolone.tw.

30 paramethasone.tw,nm.

31 methylprednisolone.tw, $\mathrm{nm}$.

32 dexamethasone.tw,nm.

33 clobetasol.tw, nm.

34 beclomethasone.tw, nm.

35 betamethasone.tw, nm.

36 budesonide.tw, $\mathrm{nm}$.

37 corticosteroid $^{*}$.tw, nm.

38 steroid $^{\star} . \mathrm{tw}, \mathrm{nm}$.

39 (efcortesol or hydrocortone or solu-cortef).tw,nm.

40 (betnelan or betnesol).tw, nm.

41 (medrone or solu-medrone or depo-medrone).tw, nm.

42 kenalog.tw, nm.

43 (novolizer or pulmicort or symbicort).tw, nm.

44 (beclometasone or aerobec or asmabec or beclazone or becodisks or becotide or clenil modulite or qvar or becloforte).tw,nm.

45 (deflazacort or calcort).tw, nm.

46 or/15-45

4714 and 46

\section{Appendix 2. Embase.com (via Elsevier) search strategy}

\#51 \#47 AND \#50149019 Dec 2010

\#50 \#48 OR \#4989794519 Dec 2010

\#49 random*:ab,ti OR placebo* OR factorial*:ab,ti OR crossover*:ab,ti OR 'cross over':ab,ti OR 'cross-over':ab,ti OR volunteer*ab,ti OR assign*:ab,ti OR allocat*:ab,ti OR ((singl ${ }^{\star}$ OR doubl $\left.{ }^{\star}\right)$ NEAR/2 (blind ${ }^{\star}$ OR mask $\left.\left.{ }^{\star}\right)\right)$ :ab,ti AND [embase]/lim86727719 Dec 2010

\#48 'randomised controlled trial'/exp OR 'single blind procedure'/exp OR 'double blind procedure'/exp OR 'crossover procedure'/exp AND [embase]/lim23386119 Dec 2010

\#47 \#14 AND \#46672519 Dec 2010

\#46 \#15 OR \#16 OR \#17 OR \#18 OR \#19 OR \#20 OR \#21 OR \#22 OR \#23 OR \#24 OR \#25 OR \#26 OR \#27 OR \#28 OR \#29 OR \#30 OR \#31 OR \#32 OR \#33 OR \#34 OR \#35

OR \#36 OR \#37 OR \#38 OR \#39 OR \#40 OR \#41 OR \#42 OR \#43 OR \#44 OR \#4554074719 Dec 2010

\#45 deflazacort:ab,ti OR calcort:ab,ti AND [embase]/lim39019 Dec 2010

\#44 beclometasone:ab,ti OR aerobec:ab,ti OR asmabec:ab,ti OR beclazone:ab,ti OR becodisks:ab,ti OR becotide:ab,ti OR 'clenil modulite':ab,ti OR qvar:ab,ti OR becloforte:ab,ti AND [embase]/lim41819 Dec 2010

\#43 novolizer:ab,ti OR pulmicort:ab,ti OR symbicort:ab,ti AND [embase]/lim28919 Dec 2010

\#42 kenalog:ab,ti AND [embase]/lim11619 Dec 2010

\#41 medrone:ab,ti OR 'solu medrone':ab,ti OR 'dep medrone':ab,ti AND [embase]/lim1319 Dec 2010

\#40 betnelan:ab,ti OR betnesol:ab,ti AND [embase]/lim2619 Dec 2010

\#39 efcortesol:ab,ti OR hydrocortone:ab,ti OR 'solu cortef':ab,ti AND [embase]/lim2419 Dec 2010

\#38 steroid*:ab,ti AND [embase]/lim15167519 Dec 2010

\#37 corticosteroid*:ab,ti AND [embase]/lim6537519 Dec 2010 
\#36 budesonide:ab,ti AND [embase]/lim360919 Dec 2010

\#35 betamethasone:ab,ti AND [embase]/lim376819 Dec 2010

\#34 beclomethasone:ab,ti AND [embase]/lim257019 Dec 2010

\#33 clobetasol:ab,ti AND [embase]/lim74619 Dec 2010

\#32 dexamethasone:ab,ti AND [embase]/lim3776219 Dec 2010

\#31 methylprednisolone:ab,ti AND [embase]/lim1045419 Dec 2010

\#30 paramethasone:ab,ti AND [embase]/lim6319 Dec 2010

\#29 prednisolone:ab,ti AND [embase]/lim1621519 Dec 2010

\#28 prednisone:ab,ti AND [embase]/lim1833919 Dec 2010

\#27 triamcinolone:ab,ti AND [embase]/lim461019 Dec 2010

\#26 corticosterone:ab,ti AND [embase]/lim1766619 Dec 2010

\#25 cortisone:ab,ti AND [embase]/lim504419 Dec 2010

\#24 cortodoxone:ab,ti AND [embase]/lim519 Dec 2010

\#23 tetrahydrocortisol:ab,ti37919 Dec 2010

\#22 pregnenolone:ab,ti AND [embase]/lim393619 Dec 2010

\#21 hydroxypregnenolone:ab,ti AND [embase]/lim50019 Dec 2010

\#20 hydrocortisone:ab,ti AND [embase]/lim1104419 Dec 2010

\#19 'pregnane derivative'/de AND [embase]/lim52719 Dec 2010

\#18 hydroxycorticosteroid*ab,ti AND [embase]/lim62919 Dec 2010

\#17 'hydroxycorticosteroid'/exp AND [embase]/lim24019 Dec 2010

\#16 glucocorticoid*:ab,ti AND [embase]/lim4210419 Dec 2010

\#15 'glucocorticoid'/exp AND [embase]/lim38055619 Dec 2010

\#14 \#1 OR \#2 OR \#3 OR \#4 OR \#5 OR \#6 OR \#7 OR \#8 OR \#9 OR \#10 OR \#11 OR \#12 OR \#1310695919 Dec 2010

\#13 's. pneumoniae':ab,ti OR 's pneumoniae':ab,ti OR 's. pyogenes':ab,ti OR 's pyogenes':ab,ti AND [embase]/lim761119 Dec 2010

\#12 'streptococcus infection'/exp AND [embase]/lim1848919 Dec 2010

\#11 streptococc*:ab,ti OR gabhs:ab,ti AND [embase]/lim5434219 Dec 2010

\#10 'streptococcus'/exp AND [embase]/lim6479619 Dec 2010

\#9 'sore throat':ab,ti OR 'sore throats':ab,ti AND [embase]/lim280919 Dec 2010

\#8 'sore throat'/de AND [embase]/lim581219 Dec 2010

\#7 pharyngotonsillit*:ab,ti AND [embase]/lim30119 Dec 2010

\#6 laryngit*:ab,ti AND [embase]/lim102019 Dec 2010

\#5 'laryngitis'/exp AND [embase]/lim320319 Dec 2010

\#4 pharyngit*:ab,ti AND [embase]/lim349219 Dec 2010

\#3 'pharyngitis'/exp AND [embase]/lim1233519 Dec 2010

\#2 tonsillit*:ab,ti AND [embase]/lim297819 Dec 2010

\#1 'tonsillitis'/exp AND [embase]/lim631419 Dec 2010

\section{FEE D B A C K}

\section{Corticosteroids as standalone or add-on treatment for sore throat, October 2014}

\section{Summary}

Just wanted to point out a possible typo under participants section:

(369 participants aged 5-21 years and 374 participants aged ${ }^{\star} 12^{\star}$ to 65 )

Thanks,

Jane Barr

I agree with the conflict of interest statement below:

I certify that I have no affiliations with or involvement in any organization or entity with a financial interest in the subject matter of my feedback.

\section{Reply}

Thank you for the comment, this has been addressed

\section{Contributors}

Gail Hayward 


\section{Corticosteroids as standalone or add-on treatment for sore throat, October 2013}

\section{Summary}

I think that the use of Relative Risks in relation to pain resolution may have resulted in misleading subgroup comparisons in this review (for example in relation to oral and IM corticosteroids). The Relative Risks of persistent pain are (RR (Non-event) $0.73 ; 95 \% \mathrm{Cl} 0.61$ to 0.86 ) and (RR (Non-event) $0.68 ; 95 \% \mathrm{Cl} 0.56$ to 0.83 ) for oral and IM treatment respectively. These are almost identical.

Odds ratios have the advantage that sub-group analysis is unchanged by whether the outcome is measured as persistent pain or resolution of pain.

\section{Chris Cates}

ccates@sgul.ac.uk

I agree with the conflict of interest statement below:

I certify that I have no affiliations with or involvement in any organization or entity with a financial interest in the subject matter of my feedback.

\section{Reply}

Thank you for the comment, we have outlined the rationale for the use of RR in the methods section

\section{Contributors}

Rafael Perera

WHAT'S NEW

\begin{tabular}{|c|c|c|}
\hline Date & Event & Description \\
\hline 14 May 2019 & $\begin{array}{l}\text { New citation required and conclusions } \\
\text { have changed }\end{array}$ & $\begin{array}{l}\text { We updated the searches. We included one new study, Hayward } \\
2017 \text {, and excluded one new clinical study (Chen 2018). Corticos- } \\
\text { teroids increased the likelihood of complete resolution of pain } \\
\text { at } 24 \text { hours by } 2.4 \text { times, and at } 48 \text { hours by } 1.5 \text { times. Corticos- } \\
\text { teroids reduced pain (assessed by visual analogue scores) by an } \\
\text { additional } 10.6 \% \text { at } 24 \text { hours. Corticosteroids reduced the mean } \\
\text { time to onset of pain relief and the mean time to complete reso- } \\
\text { lution of pain by } 6 \text { and } 11.6 \text { hours, respectively, although signifi- } \\
\text { cant heterogeneity was present. }\end{array}$ \\
\hline
\end{tabular}

14 May $2019 \quad$ New search has been performed One new author joined the review team.

\section{HISTORY}

Protocol first published: Issue 1, 2010

Review first published: Issue 10, 2012

\begin{tabular}{lll}
\hline Date & Event & Description \\
\hline 5 August 2010 & Amended & Contact details updated. \\
\hline 16 June 2010 & Amended & Contact details updated. \\
\hline
\end{tabular}

\section{CONTRIBUTIONS OF AUTHORS}

Simone de Cassan: co-wrote the 2019 review update; selected studies for the 2019 review update; conducted GRADE assessment for the 2019 review update. 
Matthew J Thompson: selected studies, extracted data, and assessed risk of bias; conducted GRADE assessment for the 2012 review. Rafael Perera: reviewed all data extracted from original publications included in both the 2012 review and 2019 update.

Paul P Glasziou: extracted data, assessed risk of bias; conducted GRADE assessment for the 2019 review.

Chris B Del Mar: selected studies, extracted data, and assessed risk of bias; conducted GRADE assessment for the 2019 review.

Carl J Heneghan: resolved any conflicts about study selection, data extraction, and 'Risk of bias' assessment for both the 2012 review and 2019 update.

Gail Hayward: co-wrote the 2012 review and 2019 update; selected studies for the 2019 update, extracted data, and assessed risk of bias; conducted GRADE assessment for the 2012 review.

All review authors revised the manuscript.

\section{DECLARATIONS OF INTEREST}

Simone de Cassan: none known.

Matthew J Thompson: investigator on one study included in this review update.

Rafael Perera: investigator on one study included in this review update.

Paul P Glasziou: none known.

Chris B Del Mar: none known.

Carl J Heneghan: $\mathrm{CH}$ is supported by the National Institute for Health Research (NIHR) School for Primary Care Research Evidence Synthesis Working Group (NIHR SPCR ESWG project 390). CH is also supported by the NIHR Oxford Biomedical Research Centre and is an NIHR Senior Investigator and Editor-in-Chief of BMJ Evidence-Based Medicine.

Gail Hayward: investigator on one study included in this review update.

\section{SOURCES OF SUPPORT}

\section{Internal sources}

- No sources of support supplied

\section{External sources}

- British Society of Antimicrobial Chemotherapy, UK

A Systematic Review Grant was awarded (GA722SRG)

\section{DIFFERENCES BETWEEN PROTOCOLANDREVIEW}

Most studies included in this review reported on resolution of symptoms using the metric of complete resolution of pain at 24 and at 48 hours. We therefore refined our primary outcome to reflect the available evidence and to focus on the most relevant symptom of sore throat: pain. We also included the outcomes of mean times to onset of pain relief and to complete resolution of pain.

\section{INDEX TERMS}

\section{Medical Subject Headings (MeSH)}

Adrenal Cortex Hormones [ ${ }^{*}$ administration \& dosage]; Anti-Bacterial Agents [ ${ }^{*}$ administration \& dosage]; Drug Therapy, Combination [methods]; Pharyngitis [*drug therapy]; Randomized Controlled Trials as Topic; Time Factors; Tonsillitis [drug therapy]; Treatment Outcome

\section{MeSH check words}

Adolescent; Adult; Child; Child, Preschool; Humans; Middle Aged; Young Adult 